\title{
Jazidas de matérias-primas líticas brasileiras: Uma visão geológica
}

\author{
Ulisses Cyrino Penha
}

Setor de Arqueologia do Museu de História Natural e Jardim Botânico da Universidade Federal de Minas Gerais - UFMG. Rua Gustavo da Silveira, 1035. Santa Inês. CEP 31080-010. Belo Horizonte, Brasil.

Email: ulisses.penha@gmail.com

\section{Resumo:}

O trabalho tem como propósito auxiliar estudantes, pesquisadores e profissionais de Arqueologia a compreenderem a potencialidade de ocorrência de jazidas das principais matérias-primas líticas no Brasil em uma escala macrorregional. Essa potencialidade é apresentada de forma qualitativa e geologicamente setorizada: áreas que ocupam $42,7 \%$ do país e geologicamente conhecidas como Escudos Cristalinos, designados das Guianas, do Brasil Central e Atlântico; e áreas distribuídas no restante do território, as Bacias Sedimentares, sendo as maiores denominadas do Amazonas, da Foz do Amazonas, do Parnaíba, Sanfranciscana, do Pantanal e do Paraná. Em seguida, a potencialidade é mostrada com relação ao seu posicionamento nos maiores domínios paisagísticos brasileiros, denominados Amazônico, Cerrado, Mares de Morros, Caatingas, Matas de Araucária, Pradarias e Faixas de Transição. A escassez de atividades de campo da maioria dos cursos brasileiros de Arqueologia e Antropologia em geral não proporciona um embasamento em Mineralogia, Geologia e Geomorfologia para o desenvolvimento de pesquisas ou trabalhos arqueológicos. Nos casos específicos que envolvem investigações voltadas aos estudos líticos, esta realidade é agravada pela carência de mapas geológicos em escala apropriada. Para auxiliar a identificação das rochas e minerais mais frequentemente encontrados nos sítios arqueológicos brasileiros com material lítico são apresentados esquemas simplificados de classificação e identificação dos mesmos. Estes esquemas são particularmente úteis para identificar a natureza de matérias-primas líticas silicosas macroscopicamente similares e de grão muito fino como sílex, cherte, calcedônia, silcrete, arenito silicificado e quartzito fino, e as formas mais frequentes de quartzo. Embora não constitua propósito da pesquisa abarcar as matérias-primas pétreas da maioria dos sítios arqueológicos do Brasil, são feitas referências às naturezas líticas das indústrias de alguns deles.

Palavras-chave: matérias-primas líticas; prospecção lítica; geoarqueologia; Brasil

\section{Introdução}

Em estudos sobre a economia de captação de matérias-primas líticas, uma questão relevante é a proveniência das jazidas dos materiais que foram potencialmente utilizados por grupos humanos no passado. Tal localização é, em muitos casos, dificultada por vários fatores, como (i) escassez de afloramentos rochosos devido aos processos de laterização,

Published by the School of History, Classics and Archaeology, University of Edinburgh ISSN: 2055-0472. URL: http://journals.ed.ac.uk/lithicstudies/

This work is licensed under a Creative Commons Attribution 2.5 UK: Scotland License. 
gerando solos e mantos de intemperismo que recobrem extensamente as rochas; (ii) afloramentos de determinadas matérias-primas com dimensões frequentemente muito reduzidas; (iii) grandes distâncias entre as possíveis jazidas e os sítios sob estudo; (iv) possibilidade de terem ocorrido intercâmbios humanos destes materiais por distâncias consideráveis; (v) escassez de mapas geológicos em escalas de detalhe e semidetalhe, inviabilizando a cartografia de eventuais jazidas líticas pequenas; e (vi) raridade de estudos petrográficos de rochas aproveitadas pelos grupos pré-históricos.

Sobre os materiais líticos, vale dizer que embora não constituam uma condição determinante per si, certas propriedades físicas (ruptibilidade, grau de fraturamento, planos preferenciais de partição, espaços vazios) e mineralógicas (teor de sílica, presença de "impurezas”) das matérias-primas líticas as tornam mais adequadas para a obtenção de determinados artefatos, seja os de gumes cortantes, os utilizados para atritar, para perfurar, ou aqueles eminentemente usados para percutir (Prous 1992). Uma abordagem conceitual neste sentido pode ser vista em Prous (1992, 2004), onde o autor discorre sobre as propriedades mencionadas e as aptidões das matérias-primas líticas.

O presente estudo aborda as principais rochas e minerais com que os arqueólogos brasileiros lidam em seus estudos sobre líticos. Em seguida, posiciona esquematicamente as suas ocorrências nos escudos cristalinos e nas bacias sedimentares, apresenta um panorama da disponibilidade das matérias-primas nos domínios paisagísticos brasileiros e fornece uma breve orientação de como identificá-las em campo ou em laboratório.

Mesmo que esta contribuição tenha um caráter abrangente, será dada uma maior ênfase às matérias-primas líticas silicosas, uma vez que a sua identificação por vezes constitui uma dificuldade entre os arqueólogos; por exemplo, designando por quartzo as variedades sílex, calcedônia etc. Vale lembrar que mesmo alguns geológos que eventualmente integram equipes arqueológicas não fazem tal identificação de modo apropriado, de modo que recomenda-se também o uso de bibliografias especializadas.

\section{Matérias-primas líticas}

De forma simplificada, a Tabela 1 traz as principais rochas ígneas, sedimentares e metamórficas, muitas delas utilizadas por grupos humanos antigos para diversas finalidades. Antes dela, é oportuno uma breve explanação sobre como esses três grupos de rochas são formados.

\section{Rochas sedimentares}

As rochas sedimentares resultam da deposição (mecânica), da precipitação (química) de sedimentos, da deposição e putrefação de vestígios orgânicos, ou ainda da combinação desses componentes, por períodos de até centenas de milhões de anos em depressões denominadas bacias sedimentares. Tais sedimentos são recobertos por outros, cuja espessura pode atingir vários quilômetros, expulsando das camadas inferiores a água (desidratação), reduzindo os espaços entre seus poros, comprimindo-os (compactação), cimentando-os (cimentação) e convertendo-os em rochas (litificação), processos esses que são agrupados sob a designação de diagênese. Embora quase sempre lidemos em Arqueologia com áreas emersas, as rochas, em seu passado geológico, podem ter pertencido a bacias formadas tanto em áreas continentais quanto oceânicas e suas dimensões oscilam desde pequenas (por exemplo, bacia de Sergipe-Alagoas, do Jatobá e Potiguar, no Nordeste brasileiro) àquelas maiores que um milhão de quilômetros quadrados (bacia do Paraná). Dentre as rochas sedimentares, as com maior teor em sílica, coesas e homogêneas, constituem as matérias-primas mais utilizadas para a obteção de artefatos cortantes ou perfurantes. 
Tabela 1. Resumo simplificado das principais matérias-primas. Em verde, materiais silicosos. Fontes principais: Suguio (1980), Sgarbi (2007), Press et al. (2008), IBGE (1999), Winge (2016).

* Embora "seixo" em Sedimentologia designe fragmentos rolados de rochas ou minerais com diâmetro situado entre $4 \mathrm{~mm}$ e $6,4 \mathrm{~cm}$, sendo os maiores denominados calhaus (de 6,4 cm a 25,6 cm) e matacões $(>25,6 \mathrm{~cm})$, respectivamente (Wentworth 1922), aqui será mantido o termo seixo para todos eles, por ser este um termo de uso corrente em Arqueologia.

** Rochas agrupadas sob o termo "rochas verdes”, ricas em minerais escuros. Elas foram usadas na confecção de lâminas de machado, mãos de pilão e de alguns batedores/percutores, desde o litoral Sul-Sudeste à Amazônia.

Table 1. Simplified abstract of the main lithic raw-materials. Siliceous materials are highlighted in green. Main sources: Suguio (1980), Sgarbi (2007), Press et al. (2008), IBGE (1999), Winge (2016).

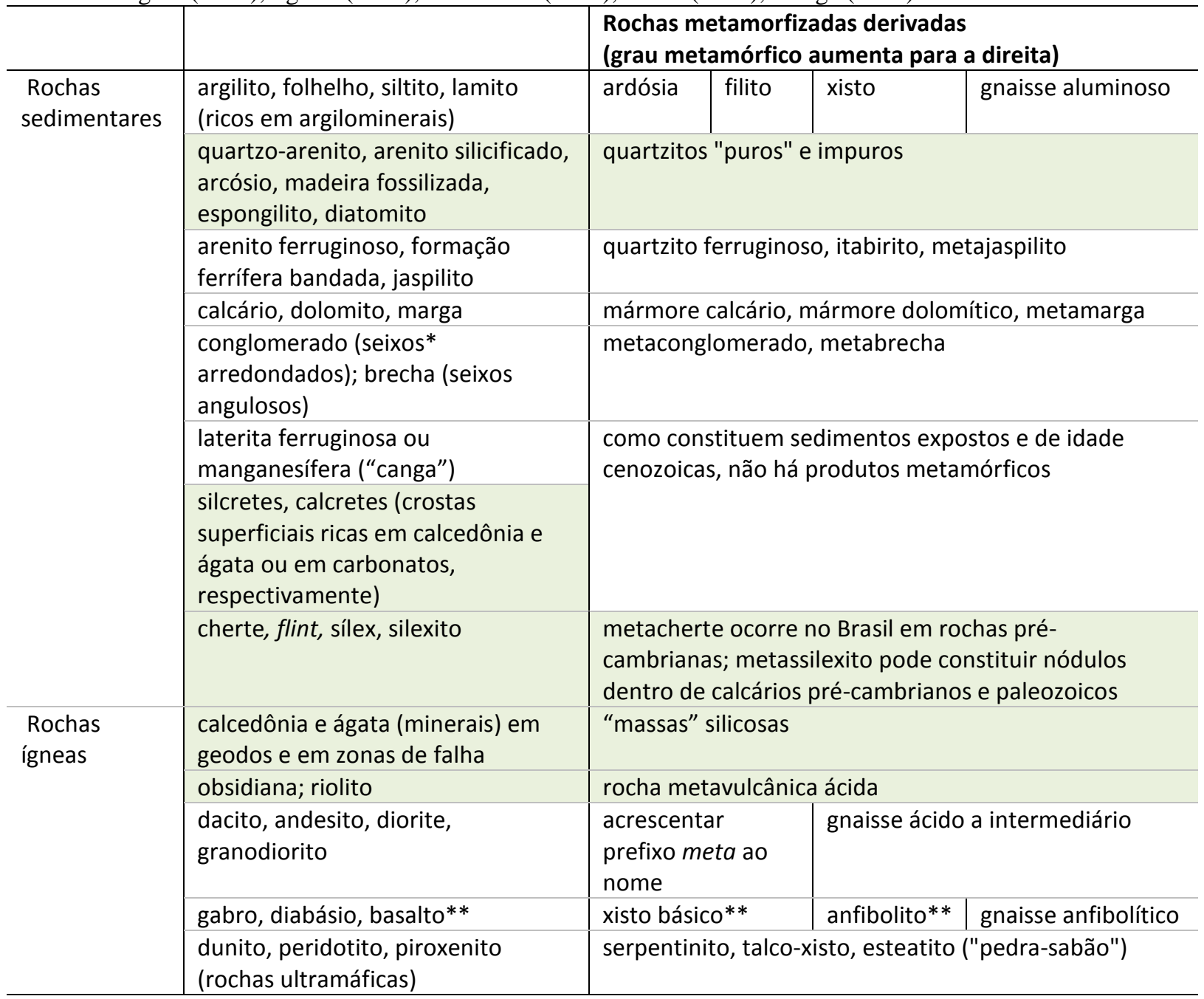

\section{Rochas ígneas}

As rochas ígneas resultam do resfriamento de magmas em profundidades crustais, desde rasas a até com vários quilômetros, ou do seu extravasamento na superfície dos continentes ou oceanos, as denominadas lavas ou derrames vulcânicos. Certas rochas ígneas, por sua homogeneidade e razoável resistência ao impacto, como granitos, diabásios e basaltos, foram úteis aos grupos humanos do passado para a elaboração de percutores, lâminas de machado, mãos de pilão e suportes como bigornas, dentre outros usos. Os minerais de rochas ígneas cristalizadas em profundidades crustais de vários ou muitos quilômetros, pelo longo tempo necessário a tal resfriamento, apresentam um crescimento que pode atingir uns poucos milímetros e desenvolvem uma textura dita fanerítica (por exemplo, granito, gabro, diorito). Por outro lado, quando o magma extravasa gerando lavas, o contraste da sua temperatura, que pode situar-se entre $650^{\circ} \mathrm{C}$ e $1.100^{\circ} \mathrm{C}$, com a temperatura da superfície é grande e os minerais 
cristalizam-se rapidamente, formando rochas de granulação fina, com texturas ditas afaníticas (por exemplo, basalto, riolito, andesito). Vale lembrar que a textura afanítica é uma característica facilitadora do lascamento controlado, quando comparada às rochas ígneas com textura fanerítica, mais úteis no passado arqueológico para instrumento que recebem percussão. A título de curiosidade, as populações pré-históricas do território brasileiro não lidaram com erupções vulcânicas e suas consequências: emissão de cinzas tóxicas e avalanches como os da Indonésia, em países situados na cordilheira andina ou no Vale Oriental da África (“Lucy” e outros australopitecíneos), uma vez que os eventos vulcânicos no Brasil remontam a tempos anteriores à existência dos hominídeos.

\section{Rochas metamórficas}

Já as rochas metamórficas, cuja gênese é algo mais complexa, derivam de rochas préexistentes, sejam elas ígneas, sedimentares ou mesmo metamórficas. Tais rochas, quando posicionadas em determinadas profundidades da crosta terrestre - mediante subsidência da bacia e recobrimento por espessas pilhas sedimentares (com mais de $10 \mathrm{~km}$ na bacia do Recôncavo, no estado da Bahia), ou por outros processos geológicos que envolvem colisões de continentes (como ocorreu nos escudos brasileiros, Figura 1) - passam por modificações mineralógicas ou texturais, por serem então submetidas a condições de pressão e de temperatura muito distintas das originais. Assim, arenitos são transformados em quartzitos, calcários em mármores, rochas sedimentares ricas em argilominerais, como os argilitos e folhelhos, tornam-se filitos e xistos, basaltos tornam-se anfibolitos e várias rochas ígneas são convertidas em gnaisses, por exemplo (Tabela 1). Tais modificações litológicas possibilitam outros usos, em relação às rochas pré-existentes, durante a elaboração dos artefatos líticos. Por exemplo, qualquer quartzito não alterado, puro e desde que isento de fraturas pouco espaçadas, proporciona uma propagação de ondas durante um impacto mais homogênea do que o arenito que lhe deu origem, pois o metamorfismo diminui consideravelmente a sua porosidade e aumenta a sua resistência, permitindo ao lascador uma melhor previsibilidade na produção das lascas conchoidais. Por outro lado, os quartzitos micáceos são menos adequados ao lascamento devido ao comportamento dúctil (maleável) de suas micas. O mesmo se pode dizer dos filitos e xistos, que, embora sejam menos porosos e mais "endurecidos" que seus precursores sedimentares, devido ao seu conteúdo em minerais micáceos ou em outros de hábito prismático (por exemplo, piroxênios) ou acicular (por exemplo, anfibólios), estruturam-se de maneira foliada. Esta foliação dificulta o lascamento, pois direciona a partição da matéria-prima segundo seus planos; contudo, em muitos casos pode constituir um elemento favorável durante a produção de pratos e outros artefatos achatados.

\section{Terrenos geológicos, domínios paisagísticos e suas principais matérias-primas líticas}

A seguir são apresentados os dois grandes domínios geológicos do território brasileiro, em mapas e seções esquemáticos e macrorregionais, e as matérias-primas a eles associadas (item 3.1). Posteriormente são mostradas, em uma abordagem ampla, as possibilidades de ocorrências das jazidas líticas nos sete domínios paisagísticos (no sentido geomorfológico) do país (item 3.2). Por fim, são mostradas tabelas simplificadas com orientações para a identificação macroscópica das matérias-primas líticas mais frequentes no Brasil (item 3.3).

\subsection{Escudos cristalinos e bacias sedimentares}

De maneira simplificada, há dois grandes contextos geológicos brasileiros: (i) amplas regiões de relevo moderado a arrasado denominadas bacias sedimentares, que ocupam 4.880.000 $\mathrm{km}^{2}$; e (ii) terrenos mais elevados, os escudos cristalinos, distribuídos nos 
3.632.000 $\mathrm{km}^{2}$ restantes (Figura 1). As denominadas serras, formadas por alinhamentos de morros que se destacam na topografia, podem ocorrer em ambos estes contextos, sendo mais frequentes nos escudos e nas bordas das bacias. É oportuno diferenciar esses terrenos, ainda que em grandes traços, pois a cada um deles se associa uma maior ou menor probabilidade geológica para conter determinados grupos de rochas e minerais.

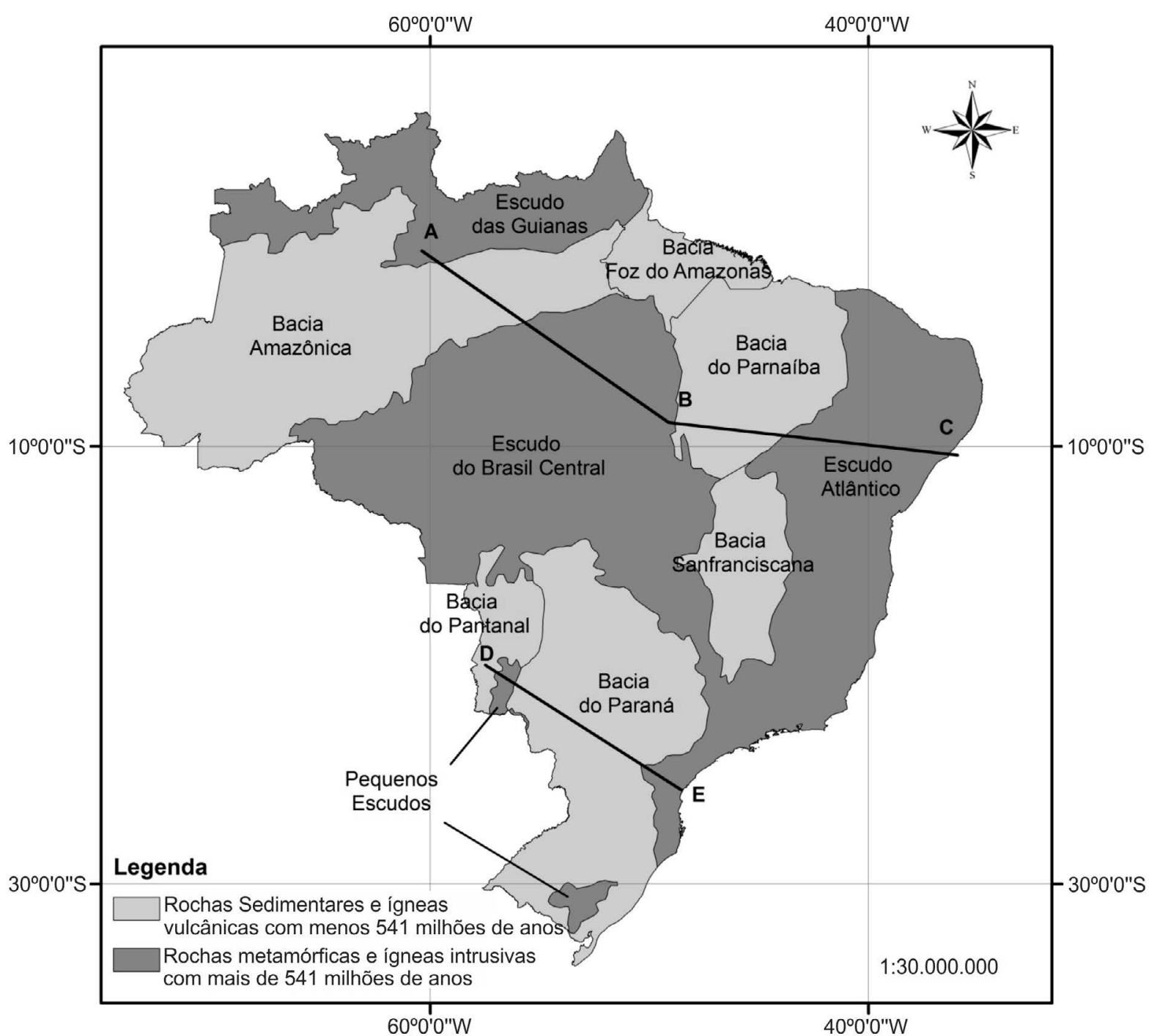

Figura 1. Divisão geológica macrorregional do Brasil, com individuação dos Escudos e Bacias Sedimentares. Os perfis A-B-C e D-E são vistos nas Figuras 2 e 3. Fonte principal: Zalán (2004).

Figure 1. Geological macroregional framework of Brazil, separating Shields and Sedimentary Basins. The A-BC and D-E profiles are exposed in the pictures 2 and 3. Main source: Zalán (2004).

As Figuras 2 e 3 constituem dois perfis de abrangência macrorregional, elaborados com o intuito de exemplificar as matérias-primas líticas mais frequentes nas áreas de escudos e de bacias. Vale ressaltar que tais perfis simplificam, para fins didáticos, a grande variedae litológica do território brasileiro, e que a abordagem a seguir constitui uma simplificação da geologia brasileira.

Para se ter um panorama detalhado da geologia dos escudos e bacias brasileiras, recomenda-se consultar Hasui et al. (2012), com a ressalva de ser esta uma obra escrita mais propriamente para o entendimento de geólogos e geomorfólogos. 


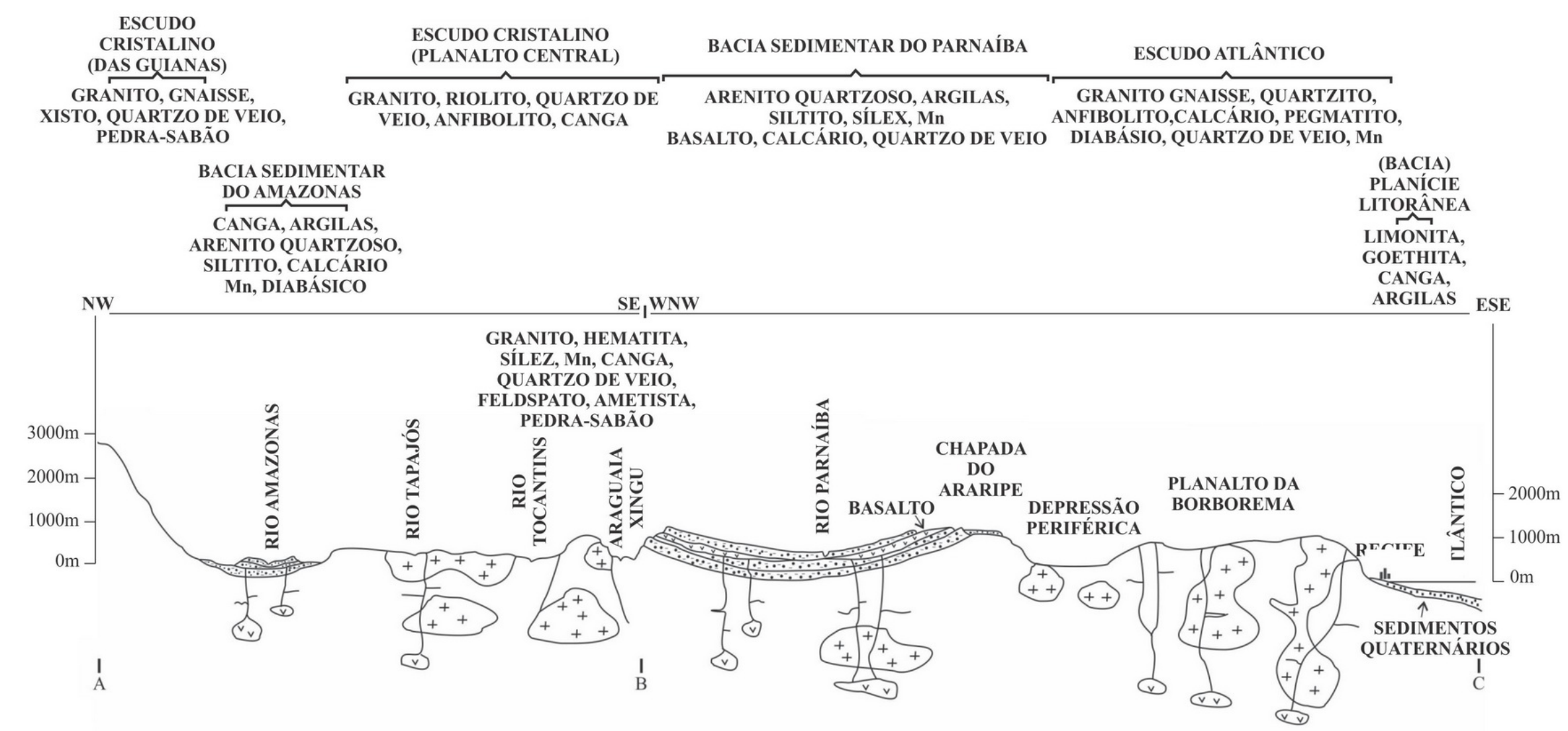

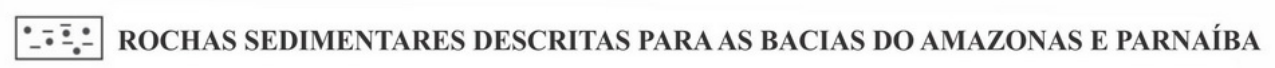

$\checkmark \vee \vee$ GABROS, DIQUES DE DIABÁSIO E BASALTOS (ROCHAS ÍGNEAS POBRES EM SÍLICA)

${ }_{+}^{+}+$GRANITOS E GRANODIORITOS (ROCHAS ÍGNEAS INTRUSIVAS SILICOSAS) COM > 541 MILHÕES DE ANOS

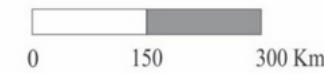

ROCHAS METAMÓRFICAS COM >541 MILHÕES DE ANOS

Figura 2. Perfil geológico simplificado A-B-C (localização na Figura 1), desde o Escudo das Guianas ao litoral nordestino, com as principais matérias-primas disponíveis. Fonte principal: Hasui et al. (2012)

Figure 2. Geological simplified A-B-C profile (localization in the Figure 1), from the Guiana Shield to the Northeast Coast, with the main available lithic raw-materiais. Main source: Hasui et al. (2012). 


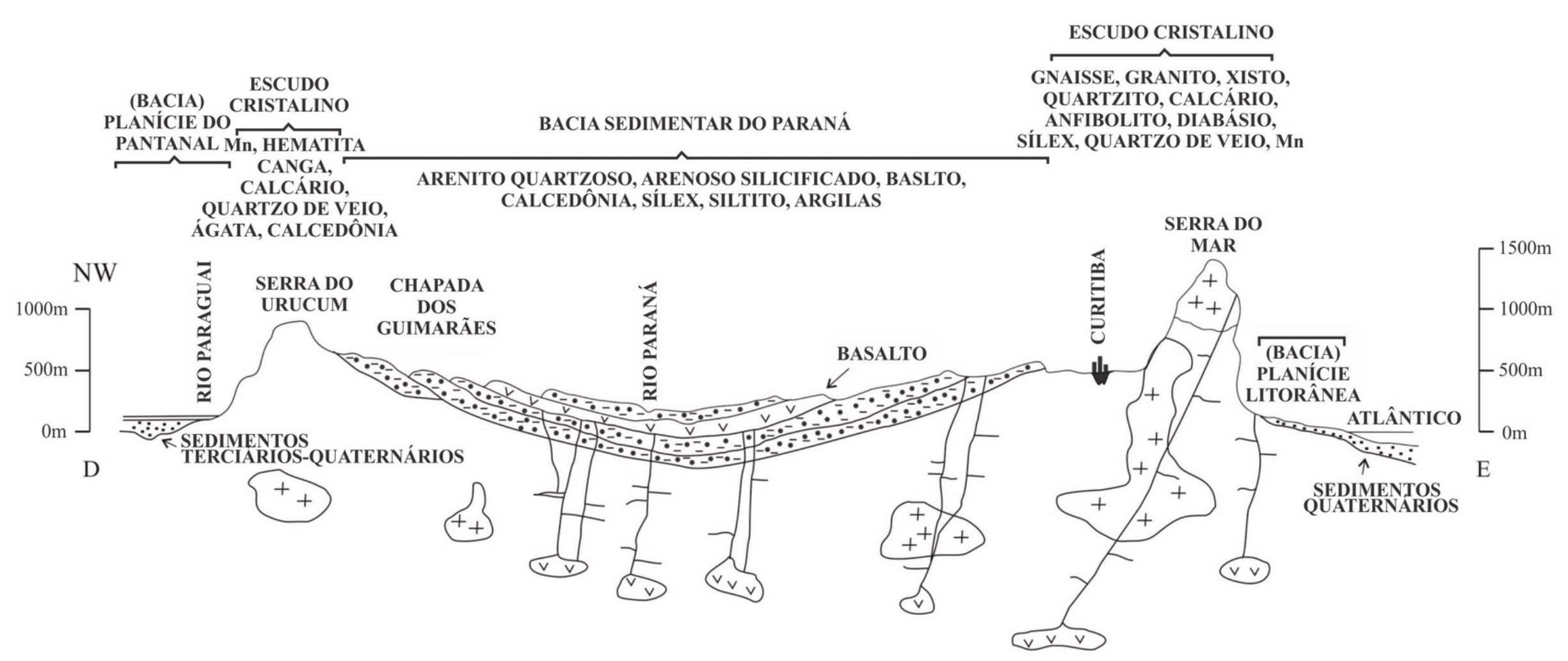

$\because=-:$ ROCHAS SEDIMENTARES DESCRITAS PARA BaCIA DO PARANÁ

$\checkmark v \vee$ GABROS, DIQUES DE DIABÁSIO E BASALTOS (ROCHAS ÍGNEAS POBRES EM SÍLICA)

$+_{+}^{+}$GRANITOS E GRANODIORITOS (ROCHAS ÍGNEAS INTRUSIVAS SILICOSAS) COM > 541 MILHÕES DE ANOS

ROCHAS METAMÓRFICAS COM > 541 MILHÕES DE ANOS

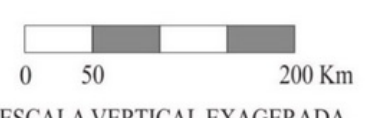

ESCALA VERTICAL EXAGERADA

Figura 3. Perfil geológico simplificado D-E do Sudeste brasileiro (localização na Figura 1), do litoral paranaense à Bacia do Pantanal, com as principais matérias-primas disponíveis. Fonte principal: Hasui et al. (2012).

Figure 3. Geological simplified D-E profile (localization in the Figure 1), from the Coast of Parana State to the Pantanal Basin, with the main available lithic raw-materiais.

Main source: Hasui et al. (2012). 
Ainda que em outros continentes existam Escudos Cristalinos em áreas topograficamente arrasadas, no Brasil esses terrenos ocupam as altitudes posicionadas entre 300 e $3.000 \mathrm{~m}$, a saber, escudos das Guianas, do Brasil Central e Atlântico. Eles são essencialmente constituídos por rochas ígneas intrusivas e metamórficas com idades comumente superiores a 541 milhões de anos. As principais matérias-primas potencialmente úteis para utilização nas indústrias líticas dos escudos são os granitos, riolitos, andesitos, granodioritos, gabros, diabásios, anfibolitos, quartzitos, gnaisses, formações ferríferas, calcários metamorfizados, pedra-sabão (esteatitos), jaspilitos, lateritas (cangas ferruginosas), quartzos com variadas colorações, formas e graus de pureza, hematita, óxidos de manganês e, raramente, sillimanita e amazonita. Figuras 2 e 3.

As Bacias Sedimentares, por seu turno, localizam-se no Brasil em regiões com altitudes inferiores a $300 \mathrm{~m}$ de altitude e com relevos desde moderados a suaves; estão preenchidas por rochas com idades em geral distribuídas de 541 milhões de anos até o Holoceno. Além das extensas bacias constantes na Figura 1, vale lembrar aquelas de tamanhos muito reduzidos e posicionadas isoladamente nos escudos cristalinos: Tacutu, no Roraima (Zalán 2004); do Fonseca, Gandarela, Gongo Soco e Juatuba, em Minas Gerais (Penha 2008); e as situadas do Sudeste brasileiro, a de Itaboraí, São José dos Campos, Resende, Volta Redonda, São Paulo e Curitiba, de idade meso-cenozoica (Melo et al. 1985). Por fim, existem as bacias da margem continental, pequenas e distribuídas esparsamente desde o Sudeste até o Norte (Zalán 2004).

As matérias-primas mais utilizadas nas indústrias líticas brasileiras, de sítios localizados em bacias sedimentares, são arenitos (puros ou não, friáveis ou compactos), arenitos e siltitos silicificados, calcários, arcósios, sílex ou silexitos e chertes (estes incomuns). Figuras 2 e 3.

Como as rochas sedimentares não são as únicas a ocorrerem nas bacias, citam-se também as matérias-primas associadas aos derrames vulcânicos, muito conhecidas, ainda que não exclusivos, da bacia do Paraná: basaltos em extensos e espessos derrames de lava; e as relacionadas aos corpos ígneos intrusivos subverticais tabulares denominados diques, sendo de diabásio os de Penatecaua e Cassiporé no Amapá, nos litorais catarinense e fluminense, e na região de Ponta Grossa, no Paraná.

Como minerais mais frequentes de utilização lítica nas bacias sedimentares tem-se ágata, calcedônia, quartzo “comum” e quartzo ametista e raras obsidianas. Figuras 2 e 3.

Além das rochas e minerais citados, ocorrem localmente depósitos formados por sedimentos quaternários, em geral inconsolidados, como cascalhos, cangas lateríticas incoesas, areias e lamas, ou consolidados, como os beachrocks (arenitos e conglomerados litorâneos ricos em fragmentos de conchas), cangas compactas, silcretes e calcretes nas regiões quentes com estações bem marcadas. Figuras 2 e 3.

Todas as matérias-primas citadas podem ter sido removidas pelos processos de intemperismo e erosão de suas áreas-fontes (mais frequentemente dos escudos, por suas maiores altitudes) e ocorrer distantes delas (nas áreas das bacias) na forma de seixos rolados em cascalhos e paleocascalhos de idades terciária e quaternária. Tais cascalheiras são depositadas em ilhas e margens fluviais, em degraus do substrato dos rios e em setores rochosos ("costões") litorâneos, especialmente quando estes últimos são próximos à foz de cursos fluviais de grande energia. Vale ressaltar que os altos cursos de afluentes de rios maiores podem localizar-se em áreas de escudos cristalinos e as rochas ígneas intrusivas e metamórficas aí situadas podem ser desagregadas e transportadas para as zonas topograficamente rebaixadas das bacias (embora tenham sido geradas fora delas), sejam bacias interiores ou costeiras. Esta condição não deve ser menosprezada como possibilidade interpretativa nos estudos sobre proveniência de líticos.

Tais ressalvas são necessárias, pois é recomendável que os arqueólogos não restrinjam a sua busca da proveniência dos materiais líticos às fontes primárias, que são os afloramentos rochosos (nas serras e chapadas, nos lajedos e margens de rios, nos “costões” do litoral do Sul 
e Sudeste ou nos maciços rochosos destacados na topografia) das áreas sob estudo, ou aos mapas geológicos existentes das mesmas áreas. Assim, é possível que seixos em praias litorânes e em rios estejam localizados a grandes distâncias das suas jazidas primárias. Além disso, os mesmos podem, em função da estação do ano em que se dão os trabalhos de campo do arqueólogo, estar submersos pela lâmina d’água dos rios (Penha 2015). É de conhecimento amplo da Arqueologia o uso frequente de seixos para obtenção de matérias-primas variadas nos tempos holocênicos.

Outro fator a ser considerado é a grande probabilidade de a identificação dos seixos dos cascalhos em questão não serem levados em conta nos levantamentos geológicos efetuados no Brasil. Esta limitação é imposta tanto pela escala do mapeamento, raramente efetuado em escala de detalhe, quanto pelo fato de seixos quaternários constituirem uma informação irrelevante aos geólogos brasileiros, formados em uma cultura acadêmica distinta daquela dos geólogos e geomorfólogos europeus e da América do Norte, onde os estudos do Quaternário recebem maior atenção.

Essas fontes secundárias de matérias-primas (seixos) foram intensamente utilizados por várias populações do passado arqueológico brasileiro, como nos sítios do Holoceno Inferior da região do Brasil Central: municípios mineiros de Buritizeiro e Jequitaí (Rodet \& Duarte 2012); vale do rio Peruaçu no norte do Estado de Minas Gerais (Rodet \& Rodet 2009); município goiano de Lajeado (Bueno 2006); e município de Oriximiná (estado do Pará, Rodet et al. 2010); apenas para citar alguns exemplos. Seixos também foram usados nos sítios sambaquieiros da zona costeira, sendo estes predominantemente constituídos por rochas ígneas intrusivas (rochas granitoides em geral e diabásios), por basaltos e por quartzo de veios.

\subsection{Domínios paisagísticos brasileiros}

Devido a abranger desde a faixa equatorial, ao norte, até latitudes bem abaixo do Trópico de Capricórnio, ao sul, as variações climáticas, vegetacionais e geomorfológicas do Brasil são amplas, o que levou o geomorfólogo Ab’Sáber (1967) a compartimentá-lo em “domínios paisagísticos” (Figura 4). Esta divisão foi baseada em elementos de abrangência macrroregional como pluviometria, formas gerais do relevo e tipos predominantes de vegetação. Vale lembrar que estes domínios podem apresentar uma amplitude geográfica distinta da categorização geológica de escudos e bacias apresentada no item 3.1, uma vez que os fatores clima, vegetação e relevo não apresentam correspondência direta com os elementos geológicos.

Resulta da divisão nos domínios paisagísticos (Figura 4) que os índices pluviométricos, a cobertura vegetal e o padrão de intemperismo a que as rochas são sujeitas, bem como a natureza e espessura dos solos que recobrem cada um deles, são distintos. É o caso da porção menor da bacia Amazônica (no sentido geológico, Figura 1, e não hidrográfico), que, por situar-se em área deprimida com vegetação densa, onde dominam os intemperismos químico e biológico das rochas, apresenta escassos afloramentos rochosos, exceto nos setores encachoeirados dos rios e igarapés, e ainda, em muitos casos, sazonalmente. Assim, o fator climático e os processos de desgaste (intemperismo) são relevantes, de modo que determinadas rochas, recobertas por solos nas terras baixas amazônicas, podem constituir afloramentos frescos na região semiárida da Caatinga no Nordeste, o que demandou economias diferenciadas de captação de recursos líticos dos grupos humanos que as frequentavam no passado arqueológico. Em zonas secas, ricas em afloramentos, a pedra pode ser uma boa opção para se fazer instrumentos, diversamente das zonas úmidas de matas, onde a variedade de matérias vegetais pode ter substituído os materiais líticos. 


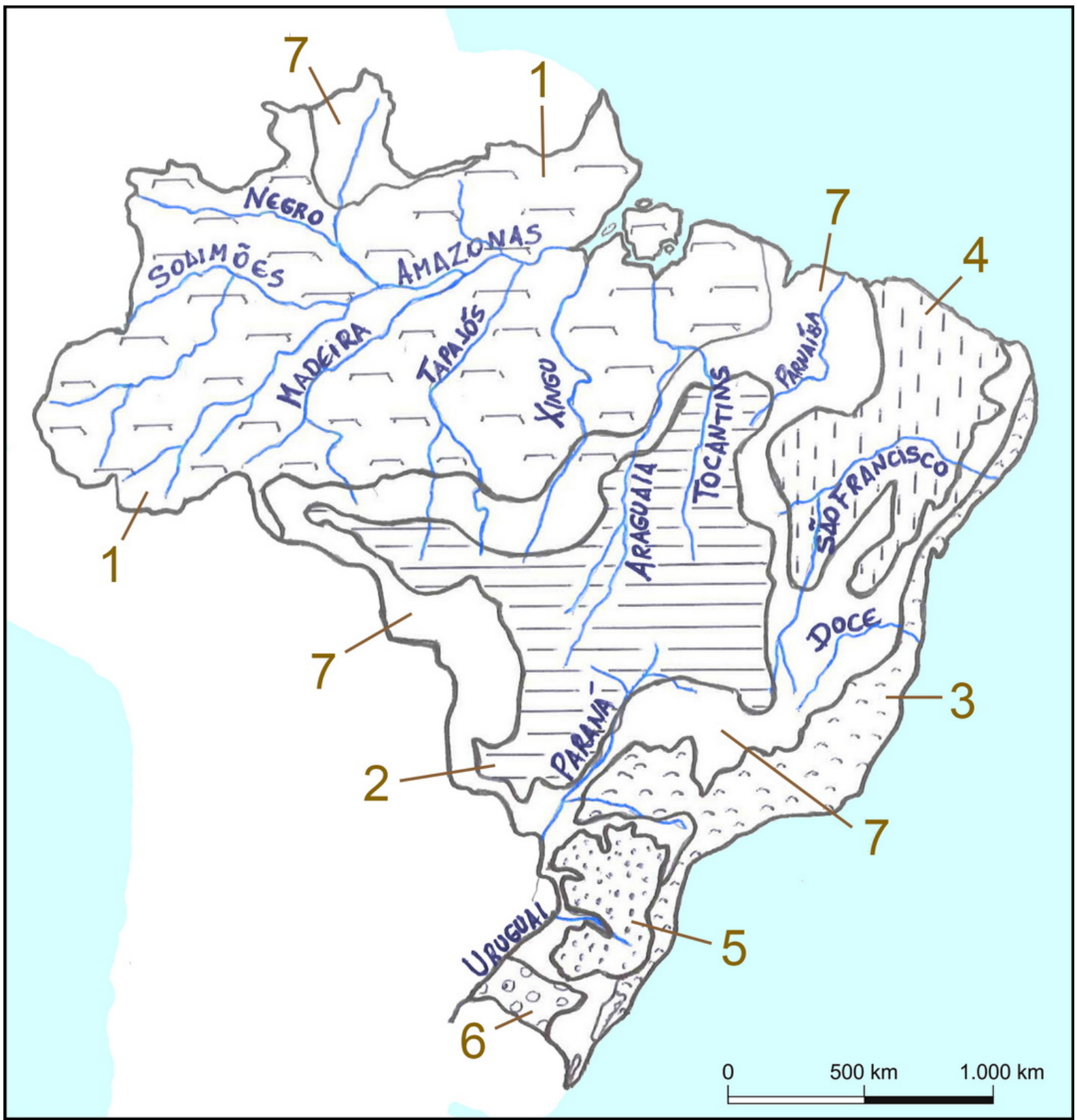

Figura 4. Principais domínios paisagísticos brasileiros segundo Ab’Sáber (1967), modificado: 1-Amazônico. 2Cerrado. 3-Mares de morros. 4-Caatingas. 5-Mata de Araucária. 6-Pradarias. 7-Faixas de transição.

Figure 4. Main Brazilian landscape according to Ab’Sáber (1967), modified: Amazônico. 2-Cerrado. 3-Mares de morros. 4-Caatingas. 5-Mata de Araucária. 6-Prairies. 7-Transitional Belts.

A Tabela 2 é uma tentativa de contribuir, de forma sintética, com dados sobre as disponibilidades e tipos de matérias-primas líticas existentes nos sete domínios morfoclimáticos e fitogeográficos (Figura 4) definidos por Ab’Sáber (1967, 2005), que são os biomas da Biologia. Vale lembrar que a Tabela 2 representa uma generalização, tendo em vista o mosaico de subambientes e microambientes em que foi subdividido cada um dos domínios paisagísticos nas últimas décadas, a partir de técnicas, recursos analíticos e escalas de mapeamento pedológicos, climáticos, botânicos, geológicos e geomorfológicos inexistentes nos decênios de 1960 a 1980.

Para utilizar as figuras e tabelas aqui apresentadas durante a análise da paisagem (em seu sentido fisiográfico) de um dado sítio arqueológico, deve-se considerar a possibilidade de esta paisagem não corresponder atualmente ao que foi presenciado pelos humanos que a 
frequentaram no passado. Isso se explica pelas alterações impressas nas paisagens devido às mudanças climáticas, vegetacionais, do regime hídrico dos rios, das taxas de erosão e de sedimentação que ocorreram após o término da última glaciação (Behling 1996; Oliveira et al. 2005). Embora estas alterações não tenham sido expressivas como no Hemisfério Norte, onde o degelo dos glaciares modificou profundamente a superfície dos continentes lá posicionados, as paisagens litorâneas brasileiras ocupadas e visitadas pelos povos sambaquieiros foram sendo gradativamente submergidas pela ascenção das águas do Atlântico da ordem de $120 \mathrm{~m}$ até 5.500 anos A.P., seguida de emersão até os tempos atuais (Suguio et al. 2005). Como estudiosos do passado humano, possivelmente temos acesso a uma fração muito pequena dos sítios holocênicos que existiram na faixa litorânea.

Outros exemplos de alterações paisagísticas foram retratadas a partir dos estudos sedimentológicos do Pleistoceno tardio de Barreto (1996) em um trecho do rio São Francisco no Estado da Bahia, tendo o autor concluído que, naquela ocasião, a descarga média deste rio era bastante inferior à atual, existindo em suas margens e leito imensas barras arenosas expostas à deflação eólica, gerando dunas de areia não observadas atualmente. E também as retrações da Floresta Úmida Amazônica durante as fases pleistocênicas mais secas, quando esta cedeu lugar a vegetações abertas (Haffer 1969; Vanzolini 1992) como o Cerrado, simultaneamente à ocupação parcial de muitas áreas de Cerrado pela Caatinga no Brasil Central.

\subsection{Identificação de matérias-primas líticas em campo}

A despeito dos avanços obtidos nas últimas décadas em alguns cursos de graduação e pós-graduação em Arqueologia e Antropologia no Brasil, inserindo em suas matrizes curriculares disciplinas de Geoarqueologia, e desenvolvendo pesquisas com a participação de profissionais de outras áreas do conhecimento, a carência de atividades de campo dos cursos em geral não proporciona aos seus egressos um embasamento mínimo em Geologia e Geomorfologia necessário ao desenvolvimento de pesquisas e de trabalhos arqueológicos (ver discussões em Araújo 2013; Penha 2015).

Entretanto, alguns exemplos de cursos onde ocorre a inserção de Geoarqueologia ou de disciplinas afins merecem menção, como, por exemplo, os da FURG (Rio Grande) e UFPel (Pelotas), no estado do Rio Grande do Sul; do MAE-USP no estado de São Paulo; da UERJ e do IAB, no estado do Rio de Janeiro; da PUC em Goiânia (estado de Goiás); da UNIVASF (São Raimundo Nonato) e UFPI (Teresina), no estado do Piauí; da UFS em Laranjeiras (estado do Sergipe); da UFPE em Recife (estado do Pernambuco); da UNIR em Porto Velho (estado de Rondônia); da UFMG em Belo Horizonte (estado de Minas Gerais).

No caso de pesquisas específicas sobre líticos, esta realidade é agravada pela carência de mapas geológicos de semidetalhe e de detalhe disponíveis ao acesso público no Brasil (Penha 2015: 71-72). Quando disponíveis, os mapas geológicos são em escala de 1:100.000 (recobrindo pouco mais que $15 \%$ do país), como em parte significativa dos estados de Minas Gerais, da Bahia e de Goiás; e raramente são em escala de 1:50.000, a exemplo de todo o estado do Rio de Janeiro e de parte do estado do Paraná. Esses mapas via de regra não atendem às necessidades da Arqueologia, pois as suas escalas não permitem a cartografia (i) da maioria das camadas de cherte, de nódulos de silexito em calcários, de faixas de sillimanita, de ocorrências de calcedônia e da maioria dos veios de quartzo; e (ii) da natureza litológica dos seixos e calhaus que constituem os cascalhos fluviais e costeiros, utilizados abundantemente no passado arqueológico como jazidas líticas em vários sítios conhecidos. 
Tabela 2. Grandes domínios paisagísticos brasileiros e síntese simplificada da disponibilidade regional de matérias-primas líticas nos flúvios e interflúvios. Principais fontes: Ab’Sáber (1967, 1971, 2005), Santos et al. (1982), Ross (1991), Suguio (2005), Latrubesse et al. (2005) e Lima da Costa et al. (2009).

Table 2. Main Brazilian landscapes realms and simplified synthesis of the regional availability of lithic raw-materials in rivers and watersheds. Main sources: Ab’Sáber (1967, 1971, 2005), Santos et al. (1982), Ross (1991), Suguio (2005), Latrubesse et al. (2005) e Lima da Costa et al. (2009).

\begin{tabular}{|c|c|c|c|c|c|c|}
\hline $\begin{array}{l}\text { Unidade } \\
\text { morfoclimática e } \\
\text { fitogeográfica }\end{array}$ & $\begin{array}{l}\text { Área e } \\
\text { precipitação } \\
\text { pluviométrica } \\
\text { anual }\end{array}$ & $\begin{array}{l}\text { Tipo predominante } \\
\text { de canal fluvial e } \\
\text { granulometria dos } \\
\text { sedimentos }\end{array}$ & $\begin{array}{l}\text { Disponibilidade de matérias-primas líticas } \\
\text { nos rios (jazidas primárias e secundárias) }\end{array}$ & $\begin{array}{l}\text { Disponibilidade de } \\
\text { matérias-primas }\end{array}$ & Solos & Principais feições de relevo \\
\hline $\begin{array}{l}\text { Depressões } \\
\text { interplanálticas } \\
\text { semiáridas do } \\
\text { Nordeste. Caatinga. } \\
\text { Inclui Planalto da } \\
\text { Borborema e } \\
\text { Depressão Sertaneja } \\
\text { do São Francisco. }\end{array}$ & $\begin{array}{l}700.000 \mathrm{a} \\
850.000 \mathrm{~km}^{2} \\
350 \text { a } 600 \mathrm{~mm}\end{array}$ & $\begin{array}{l}\text { rios entrelaçados } \\
\text { temporários } \\
\text { (exceto o São } \\
\text { Francisco e o } \\
\text { Parnaíba); } \\
\text { predomínio de } \\
\text { sedimentos grossos }\end{array}$ & $\begin{array}{l}\text { afloramentos abundantes de rochas } \\
\text { gnáissicas e graníticas, anfibolitos, xistos, } \\
\text { quartzitos, diabásios, veios de quartzo, } \\
\text { sílex, silexito; camadas de caliche ou } \\
\text { calcrete no solo; quartzitos, arenito, sílex, } \\
\text { quartzo, calcedônia e calcários (serra da } \\
\text { Capivara-PI); hematita em Xingó-SE }\end{array}$ & $\begin{array}{l}\text { abundância de } \\
\text { seixos aluviais e } \\
\text { coluviais e de } \\
\text { lajedos nos rios; } \\
\text { poucas argilas }\end{array}$ & $\begin{array}{l}\text { "pedalfer": solos rasos, } \\
\text { quimicamente ricos em } \\
\text { sais minerais e pobres } \\
\text { em matéria orgânica; } \\
\text { latossolos profundos } \\
\text { nas chapadas }\end{array}$ & $\begin{array}{l}\text { depressões intermontanas; } \\
\text { áreas de relevo arrasado } \\
\text { frequentes; vertentes } \\
\text { côncavas; inselbergs } \\
\text { (serrotes em Patos-PB, } \\
\text { Quixadá-CE); Chapada } \\
\text { Diamantina-BA; brejos de } \\
\text { altitude e de pés-de-serra }\end{array}$ \\
\hline $\begin{array}{l}\text { "Mares de morros" } \\
\text { florestados. Mata } \\
\text { Atlântica com } \\
\text { encraves de } \\
\text { araucárias e de } \\
\text { cerrados. Planaltos e } \\
\text { serras do Atlântico } \\
\text { Leste. }\end{array}$ & $\begin{array}{l}1.000 .000 \\
\mathrm{~km}^{2} ; 1.100 \mathrm{a} \\
4.500 \mathrm{~mm}\end{array}$ & $\begin{array}{l}\text { rios meandrantes e } \\
\text { anastomosados } \\
\text { perenes; } \\
\text { sedimentos de finos } \\
\text { a grossos }\end{array}$ & $\begin{array}{l}\text { afloramentos frequentes de rochas } \\
\text { gnáissicas e graníticas, xistos, anfibolitos, } \\
\text { diabásios, veios de quartzo (p. ex., nas } \\
\text { serras do Mar e da Mantiqueira); sienitos } \\
\text { (serra do Itatiaia), fonolitos (parte do litoral } \\
\text { Sudeste); arenitos e lateritas contendo } \\
\text { hematita, goethita e limonita nos } \\
\text { tabuleiros costeiros }\end{array}$ & $\begin{array}{l}\text { abundância de } \\
\text { seixos aluviais e } \\
\text { coluviais; depósitos } \\
\text { argiloso-arenosos } \\
\text { nas calhas dos rios; } \\
\text { lajedos menos } \\
\text { frequentes que na } \\
\text { Caatinga }\end{array}$ & $\begin{array}{l}\text { solos espessos, } \\
\text { lixiviados e } \\
\text { quimicamente pobres } \\
\text { nas vertentes; solos } \\
\text { quimicamente ricos nas } \\
\text { rampas de colúvio e } \\
\text { vales colmatados }\end{array}$ & $\begin{array}{l}\text { vertentes convexas, que } \\
\text { podem estar separadas por } \\
\text { vales colmatados; relevos } \\
\text { íngremes com afloramentos } \\
\text { nas serras; tabuleiros pobres } \\
\text { em afloramentos próximos à } \\
\text { costa; "pães-de-açúcar" e } \\
\text { inselbergs localizados }\end{array}$ \\
\hline $\begin{array}{l}\text { Chapadões do Brasil } \\
\text { Tropical Atlântico. } \\
\text { Cerrados penetrados } \\
\text { por florestas-galerias. } \\
\text { Inclui a Bacia } \\
\text { Sanfranciscana (MG- } \\
\text { BA) e a Chapada dos } \\
\text { Guimarães (MT). }\end{array}$ & $\begin{array}{l}1.700 .000 \mathrm{a} \\
1.900 .000 \\
\mathrm{~km}^{2} ; 1.300 \mathrm{a} \\
1.800 \mathrm{~mm} \\
\text { (duas } \\
\text { estações bem } \\
\text { marcadas) }\end{array}$ & $\begin{array}{l}\text { rios meandrantes } \\
\text { perenes; } \\
\text { sedimentos de finos } \\
\text { a grossos; incluem- } \\
\text { se alto-médios rios } \\
\text { Tocantins, Araguaia } \\
\text { e São Francisco }\end{array}$ & $\begin{array}{l}\text { afloramentos em quantidades moderadas } \\
\text { de arenitos quartzosos, arenitos } \\
\text { silicificados (Lajeado-TO), siltitos, calcários, } \\
\text { basaltos, diabásios, riolitos (nas bacias } \\
\text { sedimentares); gnaisses, granitos, } \\
\text { quartzitos, xistos, anfibolitos, veios de } \\
\text { quartzo, andesitos, riolitos (nos escudos); } \\
\text { lateritas e sílex ou silexito em bacias e } \\
\text { escudos; sillimanita em Andrelândia e nas } \\
\text { bacias do Doce e alto Jequitinhonha (MG); } \\
\text { hematita no Quadrilátero Ferrífero (MG) }\end{array}$ & $\begin{array}{l}\text { alternância de } \\
\text { trechos com e sem } \\
\text { seixos ou lajedos na } \\
\text { calha fluvial; seixos } \\
\text { de ágata e } \\
\text { calcedônia em rios } \\
\text { do Sudeste }\end{array}$ & $\begin{array}{l}\text { latossolos espessos e } \\
\text { quimicamente pobres, } \\
\text { com pouca matéria } \\
\text { orgânica; organossolos } \\
\text { "ricos" sobre os } \\
\text { basaltos e calcários da } \\
\text { bacia do Paraná, bem } \\
\text { como nas veredas }\end{array}$ & $\begin{array}{l}\text { planaltos e chapadas de } \\
\text { superfícies aplainadas com } \\
\text { lateritas frequentes; } \\
\text { terraços de cascalheiras }\end{array}$ \\
\hline $\begin{array}{l}\text { Amazônia: Terras } \\
\text { baixas florestadas. } \\
\text { Florestas úmidas. } \\
\text { Inclui parte dos } \\
\text { Escudos das Guianas }\end{array}$ & $\begin{array}{l}2.500 .000 \\
\mathrm{~km}^{2} ; 1.600 \mathrm{a} \\
3.600 \mathrm{~mm}\end{array}$ & $\begin{array}{l}\text { rios meandrantes } \\
\text { perenes (principais) } \\
\text { com planícies } \\
\text { fluviais e grande } \\
\text { número de lagos }\end{array}$ & $\begin{array}{l}\text { afloramentos em quantidades de } \\
\text { moderadas a escassas, de arenitos } \\
\text { quartzosos, siltitos, calcedônia, lateritas } \\
\text { (abaixo dos } 300 \mathrm{~m} \text {, nas Bacias); lateritas, } \\
\text { veios de quartzo, granitos, andesitos, }\end{array}$ & $\begin{array}{l}\text { poucos trechos } \\
\text { encachoeirados } \\
\text { com lajedos; } \\
\text { abundância de } \\
\text { areias, siltes e }\end{array}$ & $\begin{array}{l}\text { predominam solos } \\
\text { ácidos (lixiviados), } \\
\text { espessos e } \\
\text { quimicamente pobres; } \\
\text { áreas de terra firme }\end{array}$ & $\begin{array}{l}\text { predomínio de tabuleiros } \\
\text { extensos e planícies de } \\
\text { inundação (<300 m altitude) } \\
\text { ocupados por sedimentos } \\
\text { quaternários; morros baixos }\end{array}$ \\
\hline
\end{tabular}




\begin{tabular}{|c|c|c|c|c|c|c|}
\hline $\begin{array}{l}\text { Unidade } \\
\text { morfoclimática e } \\
\text { fitogeográfica }\end{array}$ & $\begin{array}{l}\text { Área e } \\
\text { precipitação } \\
\text { pluviométrica } \\
\text { anual }\end{array}$ & $\begin{array}{l}\text { Tipo predominante } \\
\text { de canal fluvial e } \\
\text { granulometria dos } \\
\text { sedimentos }\end{array}$ & $\begin{array}{l}\text { Disponibilidade de matérias-primas líticas } \\
\text { nos rios (jazidas primárias e secundárias) }\end{array}$ & $\begin{array}{l}\text { Disponibilidade de } \\
\text { matérias-primas }\end{array}$ & Solos & Principais feições de relevo \\
\hline e do Brasil Central. & & $\begin{array}{l}\text { (abaixo de } 300 \mathrm{~m} \\
\text { altitude); } \\
\text { predomínio de } \\
\text { sedimentos finos }\end{array}$ & $\begin{array}{l}\text { riolitos, anfibolitos, hematita, sílex ou } \\
\text { silexito e ultramáficas (nos Escudos, acima } \\
\text { dos } 300 \text { m: altos cursos dos rios Tocantins, } \\
\text { Araguaia, Tapajós, Xingu, Paru, Maicuru e } \\
\text { Trombetas); "rochas verdes" nos rios } \\
\text { Jiparaná e Trombetas, ambos na Amazônia; } \\
\text { Serra dos Carajás (PA) }\end{array}$ & $\begin{array}{l}\text { argilas ("argila de } \\
\text { Belterra"); seixos } \\
\text { em geral escassos }\end{array}$ & $\begin{array}{l}\text { terciárias com } \\
\text { fertilidade natural } \\
\text { inferior aos das } \\
\text { planícies quaternárias, } \\
\text { que são fertilizadas } \\
\text { anualmente pelas } \\
\text { enchentes; latossolos } \\
\text { amarelos nas bacias e } \\
\text { vermelhos nos escudos }\end{array}$ & $\begin{array}{l}\text { (nos Escudos, por exemplo, } \\
\text { altos cursos do Xingu e do } \\
\text { Tapajós); terraços } \\
\text { sustentados por espessas } \\
\text { cascalheiras ou por cangas } \\
\text { lateríticas }\end{array}$ \\
\hline $\begin{array}{l}\text { Faixas de Transição. } \\
\text { Zona dos Cocais, } \\
\text { Agreste, Meio-Norte, } \\
\text { Pantanal Mato- } \\
\text { grossense, centro da } \\
\text { Bahia, noroeste de } \\
\text { São Paulo. }\end{array}$ & $\begin{array}{l}2.600 .000 \mathrm{a} \\
2.800 .000 \mathrm{~km}^{2}\end{array}$ & $\begin{array}{l}\text { rios meandrantes; } \\
\text { Parnaíba, alto } \\
\text { Xingu, alto Madeira, } \\
\text { Juruena e Teles } \\
\text { Pires }\end{array}$ & $\begin{array}{l}\text { afloramentos de ausentes a escassos nas } \\
\text { áreas de relevo rebaixado e plano (Zona } \\
\text { dos Cocais-MA, Pantanal-MT e MS); } \\
\text { afloramentos frequentes de granitos e } \\
\text { gnaisses (Agreste-RN-PB-PB-AL, centro da } \\
\text { Bahia); Pantanal: calcário, hematita, } \\
\text { quartzo, ágata, sílex, cornalina, calcedônia; }\end{array}$ & \multicolumn{3}{|c|}{$\begin{array}{l}\text { matérias-primas líticas, tipos de solos e feições de relevo constituem mosaicos } \\
\text { das unidades morfoclimáticas e fitogeográficas vizinhas }\end{array}$} \\
\hline $\begin{array}{l}\text { Matas de Araucária. } \\
\text { Planaltos } \\
\text { Subtropicais da } \\
\text { região Sul. }\end{array}$ & $\begin{array}{l}400.000 \mathrm{~km}^{2} \\
>1.000 \\
\mathrm{~mm} / \mathrm{ano}\end{array}$ & $\begin{array}{l}\text { rios retilíneos } \\
\text { perenes, em vales } \\
\text { encaixados; alto } \\
\text { Paranapanema; } \\
\text { porção esquerda da } \\
\text { bacia do Uruguai, } \\
\text { sedimentos grossos }\end{array}$ & $\begin{array}{l}\text { afloramentos frequentes de quartzo- } \\
\text { arenitos e basaltos na bacia do Paraná, } \\
\text { além de ocorrências menores de diabásio, } \\
\text { arenito silicificado, quartzo leitoso e } \\
\text { ametista (Ametista do Sul-RS), calcedônia e } \\
\text { ágata; riolitos e dacitos na região de } \\
\text { Palmas-Chapecó (SC); }\end{array}$ & $\begin{array}{l}\text { trechos com lajedos } \\
\text { frequentes; seixos } \\
\text { de ágata, } \\
\text { calcedônia, arenito }\end{array}$ & $\begin{array}{l}\text { solos arenosos sobre } \\
\text { formações areníticas; } \\
\text { "terra roxa" argilosa } \\
\text { sobre basaltos }\end{array}$ & $\begin{array}{l}\text { planaltos e chapadas com } \\
\text { vertentes convexas }\end{array}$ \\
\hline $\begin{array}{l}\text { Pradarias. Coxilhas } \\
\text { ("pampas") } \\
\text { subtropicais no } \\
\text { Sudeste gaúcho. }\end{array}$ & $\begin{array}{l}80.000 \mathrm{~km}^{2} \\
1.200 \\
\mathrm{~mm} / \text { ano }\end{array}$ & $\begin{array}{l}\text { rios meandrantes } \\
\text { perenes: Ibicuí e } \\
\text { Jacuí; sedimentos } \\
\text { finos }\end{array}$ & $\begin{array}{l}\text { afloramentos em quantidades moderadas } \\
\text { de gnaisses, granitos, "rochas verdes" e } \\
\text { veios de quartzo no Escudo; arenitos e } \\
\text { basaltos na bacia do Paraná, com } \\
\text { ocorrências localizadas de riolitos (Cerro } \\
\text { Chato) e de madeira fóssil na região de } \\
\text { Mata-Santa Maria; quartzo e calcedônia }\end{array}$ & $\begin{array}{l}\text { aluviões com leitos } \\
\text { arenosos; } \\
\text { localmente seixos } \\
\text { de basalto e arenito } \\
\text { (na bacia) e de } \\
\text { granitos/xistos no } \\
\text { vale do Jacuí }\end{array}$ & solos arenosos na bacia & $\begin{array}{l}\text { relevo arrasado com suaves } \\
\text { ondulações }\end{array}$ \\
\hline
\end{tabular}


A partir do exposto, produziram-se as Tabelas 2 e 3 com o objetivo de auxiliar minimamente os arqueólogos na identificação macroscópica das rochas e minerais mais frequentes utilizados no passado arqueológico como matérias-primas líticas no Brasil. As referidas tabelas constituem uma simplificação para uso em campo e não dispensam a consulta aos manuais de mineralogia (Dana \& Hurlbut 1974; Cornejo \& Bartorelli 2010; Klein \& Dutrow 2012; Barthelmy 2014) e de petrografia macroscópica (Sgarbi 2007, Winge 2016). O apoio de geólogos de universidades e do Serviço Geológico do Brasil-CPRM também pode ser de grande valia.

\section{Matérias-primas líticas silicosas brasileiras mais frequentes}

Como o presente trabalho é direcionado às matérias-primas silicosas, salientam-se, para a nomenclatura e definição das mesmas, os trabalhos europeus de Hallsworth \& Knox (1999), Prichystal (2010) e Brandl (2010), e, no Brasil, os de Araújo (1991, 1992), Prous et al. (2009) e Penha e Prous (2017). A Tabela 4 contém elementos que podem auxiliar o arqueólogo a distinguir em campo várias matérias-primas líticas.

Os materiais silicosos em geral se prestam mais ao lascamento controlado que outras matérias-primas por serem duros ( $>7$ na escala de Mohs), em geral coesos e homogêneos e por se partirem em fraturas conchoidais no lascamento. São denominadas "frágeis" por muitos pré-historiadores, termo equivalente ao conceito de “incompetente” ou "rúptil” dos geólogos.

Uma das matérias-primas silicosas bastante utilizadas arqueologicamente é o sílex. Tratase de uma rocha formada pela precipitação química de sílica $\left(\mathrm{SiO}_{2}\right)$ micro e criptocristalina na forma dos minerais calcedônia e ágata. Esta precipitação pode ocorrer durante a diagênese (no interior de calcários, dolomitos ou folhelhos) ou pelo hidrotermalismo (fluidos quentes que percolam espaços intergranulares e fraturas das rochas), segundo Suguio (2007).

Enquanto que nos calcários o sílex ocorre geralmente em corpos muito pequenos (nódulos e lentes), nas rochas hidrotermalizadas (em sua maioria, rochas ígneas e metamórficas) ele forma massas silicosas com formato de veios, bolsões ou preenchendo fraturas. Quando tais sílex estavam em meio às rochas acima citadas, sem alteração intempérica considerável, é plausível admitir que a sua utilização no passado arqueológico tenha sido restrita pela dificuldade de serem dali retirados. Por outro lado, nos casos onde o intemperismo, a erosão e o transporte os disponibilizaram como seixos em colúvios, em cascalhos litorâneos e fluviais, seu uso por grupos humanos tornou-se facilitado. Devemos, portanto, estar atentos aos cascalhos como possível fonte destas e de outras matérias-primas líticas.

Embora afloramentos de calcários mesozoicos e cenozoicos no Brasil não sejam frequentes como na América do Norte, África, Oriente Médio e China (Sallun Filho \& Karmann 2012), localmente na costa brasileira (João Pessoa, na Paraíba) e no interior do país (por exemplo em Rio Claro, estado de São Paulo, e localmente na Chapada do Araripe, no Pernambuco), a maioria das ocorrências dessas rochas tem idade pré-cambriana ( $>541$ milhões de anos). Como os calcários são os mais frequentes hospedeiros dos nódulos de sílex, e como no Brasil a maior parte destas rochas foi metamorfizada, recristalizando-as, isso reforça a suposição acima sobre a dificuldade de extração humana pré-histórica destas matérias-primas. É o caso dos calcários dos grupos Una, Bambuí, Corumbá e Capiru, aflorantes nos estados da Bahia, Minas Gerais, Tocantins, São Paulo e Paraná; e dos situados ao longo do alto-médio rio São Francisco, desde o município de Lagoa dos Patos até o de Montalvânia, em Minas Gerais. Nos níveis inferiores de alguns sítios arqueológicos (regiões de Santa Elina, no estado do Mato Grosso; sítios da Lapa Vermelha IV, em Confins, em 
Minas Gerais), certos calcários e dolomitos foram lascados no passado arqueológico, porém com resultados inferiores aos obtidos em materiais silicosos.

Tabela 3. Critérios gerais para distinção em campo dos principais minerais brasileiros, muitos deles utilizados por grupos humanos no passado arqueológico. Fontes principais: Akhavan (2010), Dana \& Hurlbut (1974), Hasui et al. (2012).

Table 3. General criteria for field distinction of the main Brazilian minerals, many of them used by human groups in the archaeological past. Main sources: Akhavan (2010), Dana \& Hurlbut (1974), Hasui et al. (2012).

\begin{tabular}{|c|c|c|}
\hline Minerais & Algumas propriedades distintivas & Áreas de ocorrência (alguns exemplos) \\
\hline $\begin{array}{l}\text { quartzo de } \\
\text { veio }\end{array}$ & $\begin{array}{l}\text { não é riscado pelo aço; fratura } \\
\text { conchoidal; branco ("leitoso"); } \\
\text { sem faces; não se altera, } \\
\text { destacando-se na rocha alterada } \\
\text { encaixante; pode ser maciço ou } \\
\text { microfraturado }\end{array}$ & $\begin{array}{l}\text { ocorre como lentes, filões e corpos tabulares } \\
\text { preenchendo fraturas e falhas em rochas } \\
\text { variadas, especialmente em ígneas intrusivas e } \\
\text { metamórficas (escudos cristalinos); em seixos } \\
\text { fluviais nessas áreas e a juzante delas; } \\
\text { sambaquis do Sul-Sudeste e médio rio } \\
\text { Tocantins-GO }\end{array}$ \\
\hline $\begin{array}{l}\text { quartzo } \\
\text { monocristal e } \\
\text { em drusas }\end{array}$ & $\begin{array}{l}\text { não é riscado pelo aço; fratura } \\
\text { conchoidal; incolor, branco, } \\
\text { amarelo (citrino), verde, marrom } \\
\text { (fumê) ou roxo (ametista); com } \\
\text { faces }\end{array}$ & $\begin{array}{l}\text { áreas de basaltos no Rio Grande do Sul, de } \\
\text { arenitos em Carajás-PA e de quartzitos em } \\
\text { Caetité-BA (roxo); áreas de pegmatitos no leste } \\
\text { mineiro (incolor); associado a quartzo de veio } \\
\text { em escudos (incolor, branco) e em seixos } \\
\text { fluviais a juzante dessas áreas }\end{array}$ \\
\hline $\begin{array}{l}\text { calcedônia, } \\
\text { ágata, opala } \\
\text { e jaspe }\end{array}$ & $\begin{array}{l}\text { não são riscados pelo aço; fratura } \\
\text { conchoidal; cores variadas, sendo } \\
\text { o jaspe em geral vermelho; } \\
\text { estrutura em fibras paralelas } \\
\text { (calcedônia) ou concêntricas } \\
\text { (ágata); opala e jaspe são opacos e } \\
\text { os demais, translúcidos }\end{array}$ & $\begin{array}{l}\text { frequentes em rochas vulcânicas (basaltos da } \\
\text { bacia do Paraná, para as } 3 \text { primeiras); em } \\
\text { jaspilitos nas regiões de Lagoa Formosa-MG, de } \\
\text { Corumbá-MS e de Carajás-PA; em seixos } \\
\text { fluviais nessas áreas }\end{array}$ \\
\hline $\begin{array}{l}\text { madeira } \\
\text { silicificada }\end{array}$ & $\begin{array}{l}\text { não é riscada pelo aço; cores } \\
\text { variadas; pode manter a estrutura } \\
\text { da madeira; rara }\end{array}$ & $\begin{array}{l}\text { regiões de Santa Maria-RS na bacia do Paraná e } \\
\text { de Filadélfia-TO na bacia do Parnaíba e em } \\
\text { seixos fluviais a juzante delas }\end{array}$ \\
\hline $\begin{array}{l}\text { hematita } \\
\mathrm{Fe}_{2} \mathrm{O}_{3}\end{array}$ & $\begin{array}{l}\text { não é riscada pelo aço; preta, } \\
\text { marrom, vermelha; maciça ou em } \\
\text { cacho de uva (botrioidal) ; traço } \\
\text { vermelho na cerâmica; densa; } \\
\text { brilho metálico }\end{array}$ & \multirow{3}{*}{$\begin{array}{l}\text { comuns em cangas ferruginosas, a maioria } \\
\text { situada sobre formações ferríferas dos escudos } \\
\text { e bacias; abundantes em Urucum-MS, Carajás- } \\
\text { PA, Serra do Navio-AP, Caetité-BA e } \\
\text { Quadrilátero Ferrífero-MG; limonita frequente } \\
\text { em falésias do arenito Barreiras, desde o litoral } \\
\text { capixaba ao litoral paraense; hematita em } \\
\text { seixos fluviais de todas essas regiões }\end{array}$} \\
\hline $\begin{array}{l}\text { limonita } \\
\mathrm{Fe}_{2} \mathrm{O}_{3} \cdot \mathrm{nH}_{2} \mathrm{O}\end{array}$ & $\begin{array}{l}\text { não é riscada pelo aço; ocre, } \\
\text { vermelha; estrutura maciça ou } \\
\text { botrioidal; traço ocre na cerâmica; } \\
\text { sem brilho }\end{array}$ & \\
\hline $\begin{array}{l}\text { pirolusita } \\
\mathrm{MnO}_{2}\end{array}$ & $\begin{array}{l}\text { não é riscada pelo aço; friável; } \\
\text { negra; densa; brilho metálico; } \\
\text { opaca; suja os dedos }\end{array}$ & \\
\hline $\begin{array}{l}\text { feldspato } \\
\text { (inclui a } \\
\text { amazonita) }\end{array}$ & $\begin{array}{l}\text { não é riscado pelo aço; branco, } \\
\text { cinza e róseo (amazonita é verde e } \\
\text { rara); com faces; altera-se para } \\
\text { caulim }\end{array}$ & $\begin{array}{l}\text { áreas de rochas ígneas e metamórficas dos } \\
\text { Escudos; em cristais grandes nos pegmatitos } \\
\text { (por exemplo, vales do Doce e Jequitinhonha- } \\
\text { MG); e em seixos fluviais a juzante delas }\end{array}$ \\
\hline sillimanita & $\begin{array}{l}\text { não é riscada pelo aço; marrom, } \\
\text { cinza, verde; fibrosa, tenaz e } \\
\text { densa; rara }\end{array}$ & $\begin{array}{l}\text { jazidas primárias em certos xistos e gnaisses } \\
\text { (aluminosos) dos Escudos; como seixos (vales } \\
\text { dos rios Doce e Jequitinhonha-MG) }\end{array}$ \\
\hline
\end{tabular}


Tabela 4. Critérios gerais para distinção em campo das principais rochas brasileiras. Fontes principais: Suguio (1980), Sgarbi (2007), Williams et al. (1970), IBGE (1999), Winge (2016).

Table 4. General criteria to field recognizing of the main Brazilian rocks. Main sources: Suguio (1980), Sgarbi (2007), Williams et al. (1970), IBGE (1999), Winge (2016).

\begin{tabular}{|c|c|c|}
\hline Rochas & Algumas propriedades distintivas & $\begin{array}{l}\text { Áreas de ocorrência (alguns } \\
\text { exemplos) }\end{array}$ \\
\hline $\begin{array}{l}\text { laterita rica em } \\
\text { óxidos e } \\
\text { hidróxidos de } \\
\text { ferro }\end{array}$ & $\begin{array}{l}\text { riscada pelo aço; negra, roxa, vermelha; } \\
\text { traço vermelho; em concreções isoladas } \\
\text { formando camadas coesas (fragmentos } \\
\text { cimentados) }\end{array}$ & $\begin{array}{l}\text { áreas com rochas ferruginosas: } \\
\text { Quadrilátero Ferrífero, Carajás e } \\
\text { serras do Urucum e do Espinhaço; } \\
\text { chapadas do Brasil Central }\end{array}$ \\
\hline $\begin{array}{l}\text { calcário, } \\
\text { dolomito, } \\
\text { mármore }\end{array}$ & $\begin{array}{l}\text { facilmente riscáveis pelo aço; percutidas } \\
\text { com martelo emitem som submetálico; } \\
\text { efervescem com HCl }\end{array}$ & $\begin{array}{l}\text { regiões cársticas dos Escudos e } \\
\text { Bacias ( } 200.000 \mathrm{~km}^{2} \text { do país) }\end{array}$ \\
\hline sílex ("silexito") & $\begin{array}{l}\text { não riscável pelo aço; opaco; fratura } \\
\text { conchoidal; maciço ou bandado, "massa" } \\
\text { silicosa (isenta de grãos) }\end{array}$ & $\begin{array}{l}\text { em nódulos nos calcários e folhelhos } \\
\text { (bacia do Paraná); em silcretes (vale } \\
\text { do Peruaçu-MG, serra da Capivara- } \\
\text { PI); em zonas de falha }\end{array}$ \\
\hline siltito & $\begin{array}{l}\text { facilmente riscado pelo aço; fratura pode } \\
\text { ser conchoidal (quando silicoso), em geral } \\
\text { maciço }\end{array}$ & \multirow{2}{*}{$\begin{array}{l}\text { em camadas geralmente contínuas } \\
\text { das Bacias ( } 57,3 \% \text { do Brasil); Santa } \\
\text { Elina-MS (bacia do Paraná); Serra da } \\
\text { Capivara-PI (bacia do Parnaíba) }\end{array}$} \\
\hline $\begin{array}{l}\text { quartzo- } \\
\text { arenito } \\
\text { (arenito } \\
\text { "puro") }\end{array}$ & $\begin{array}{l}\text { não é riscado pelo aço; branco; vermelho e } \\
\text { castanho (quando ferruginoso); fratura não } \\
\text { conchoidal; formado por grãos de areia } \\
\text { (maioria de quartzo); em geral poroso; } \\
\text { maciço ou bandado }\end{array}$ & \\
\hline $\begin{array}{l}\text { arenito } \\
\text { silicificado }\end{array}$ & $\begin{array}{l}\text { não riscável pelo aço; vermelho e castanho; } \\
\text { fratura conchoidal; grãos de quartzo e } \\
\text { cimento silicoso formam rocha homogênea; } \\
\text { pouco poroso; maciço }\end{array}$ & $\begin{array}{l}\text { associados aos basaltos da bacia do } \\
\text { Paraná, desde o Rio Grande do Sul } \\
\text { até Goiás; esparsamente no arenito } \\
\text { Urucuia (MG, BA); Serranópolis (GO) }\end{array}$ \\
\hline quartzito & $\begin{array}{l}\text { não é riscado pelo aço; em geral branco, } \\
\text { bege ou cinza; fratura conchoidal quando } \\
\text { os grãos são finos; pouco poroso; maciço } \\
\text { ou foliado }\end{array}$ & $\begin{array}{l}\text { regiões metamórficas dos Escudos } \\
\text { (por exemplo, serras do Espinhaço, } \\
\text { do Cabral e da Canastra-MG) }\end{array}$ \\
\hline $\begin{array}{l}\text { granito e } \\
\text { gnaisse }\end{array}$ & $\begin{array}{l}\text { cristais de quartzo, feldspato e de minerais } \\
\text { escuros visíveis a olho nu; veios de quartzo } \\
\text { podem preencher fraturas; ásperos e algo } \\
\text { porosos }\end{array}$ & $\begin{array}{l}\text { predominantemente nas áreas } \\
\text { ígneas dos Escudos, incluindo os } \\
\text { "costões" do litoral Sul-Sudeste }\end{array}$ \\
\hline $\begin{array}{l}\text { basalto e } \\
\text { diabásio }\end{array}$ & $\begin{array}{l}\text { negros; cristais escuros e feldspato visíveis } \\
\text { com lupa de bolso; maciços; basalto pode } \\
\text { conter ametista e calcedônia; ásperos } \\
\text { (exceto quando seixos) e porosos }\end{array}$ & $\begin{array}{l}\text { basalto em bacias; diabásio em } \\
\text { bacias e escudos; Carajás-PA; litoral } \\
\text { Sul-Sudeste }\end{array}$ \\
\hline anfibolito & $\begin{array}{l}\text { preto e verde escuro; cristais de anfibólio e } \\
\text { feldspato orientados e distinguíveis com } \\
\text { lupa de bolso; foliado }\end{array}$ & \multirow{3}{*}{$\begin{array}{l}\text { predominantemente nas áreas } \\
\text { metamórficas dos Escudos }(42,7 \% \\
\text { do Brasil), associadas ou não a } \\
\text { gnaisses e granitos }\end{array}$} \\
\hline filito e xisto & $\begin{array}{l}\text { riscáveis pelo aço; em geral cinza; cristais } \\
\text { de micas orientadas e distinguíveis com } \\
\text { lupa de bolso; foliados; impermeáveis } \\
\text { (salvo quando fraturados) }\end{array}$ & \\
\hline $\begin{array}{l}\text { pedra-sabão ou } \\
\text { esteatito }\end{array}$ & $\begin{array}{l}\text { riscável pela unha; em vários tons de verde } \\
\text { e cinza; untuosa ao tato; foliada; cristais } \\
\text { fibrosos; de fácil entalhe; impermeável }\end{array}$ & \\
\hline
\end{tabular}


Diferentemente do Brasil, em algumas regiões como o sul e leste da Inglaterra, o litoral da Dinamarca e do norte da Alemanha e a Isle de France, os nódulos da variedade escura do sílex denominada flint são hospedados por calcários mesozoicos pouco litificados, os chalks. Nestas regiões os nódulos podem ser facilmente extraídos, além de também ocorrerem como seixos (Shepherd 1972, Knauth 1994).

\section{Sílex}

Como exposto, as modificações nos calcários e dolomitos acima citadas afetaram também os nódulos e lentes de sílex, aumentando a granulação das fibras de calcedônia e do cimento de ágata. Outra modificação diz respeito ao fraturamento desses materiais, gerando vazios que possibilitam o alojamento de impurezas (em geral argilominerais, calcita, sílica e óxidos ou hidróxidos de ferro e de manganês) que reduzem a sua homogeneidade original. Estas diferenças têm levado vários arqueólogos a denominar os sílex pré-cambrianos brasileiros de silexitos, embora os manuais de mineralogia não façam tal distinção (Bates \& Jackson 1987).

\section{Silcrete}

Material quimicamente similar ao sílex é o silcrete (Winge et al. 2016), que ocorre na forma de carapaças silicosas endurecidas (duricrusts), constituídas por calcedônia, opala e quartzo de crescimento secundário, formadas à superfície (ao nível do solo). Quando são transportados por gravidade e por chuvas encosta abaixo, até alcançar algum curso d'água e serem convertidos em seixos rolados, tais silcretes são indistinguíveis, sem o recurso de análises químicas e de uma compreensão geológica da área, dos sílex gerados no interior das rochas calcárias ou das rochas hidrotermalizadas hospedeiras.

\section{Quartzo de veio}

De ocorrência num grande espectro de ambientes geológicos é o quartzo de veio, forma de sílica em que o conteúdo em água é inferior a 0,1\%, e as impurezas situam-se entre 0,01 e 0,5\%. Este mineral pode ser de opaco ("leitoso") a translúcido e tem a mesma composição $\left(\mathrm{SiO}_{2}\right)$ dos cristais individualizados de quartzo (quartzo hialino). Estes podem ultrapassar, nas rochas ígneas denominadas pegmatitos, $1 \mathrm{~m}$ de comprimento. Os veios de quartzo podem ter uma geometria tabular, cilíndrica, dobrada ou irregular (“bolsões”) e suas dimensões oscilam desde milimétricas a quilométricas. Talvez se trate da matéria-prima pétrea mais utilizada pelos pré-históricos em todos os continentes (Prous 2004) por ser facilmente disponível nas rochas ígneas, das ácidas às intermediárias, e nas rochas metamórficas em geral, especialmente em zonas de fraturas abertas. Este quartzo pode apresentar muitos "defeitos" (planos de clivagem, fraturas com infiltração de óxidos etc.), além de mostrar às vezes textura policristalina ou sacaroidal, propriedades estas que dificultam a obtenção da fratura conchoidal. Por isto, várias formas de quartzo são geralmente trabalhadas sobre bigorna, gerando diversos produtos de lascamento, dentre eles a fratura em split, conforme constatado em sambaquis ao longo da costa meridional brasileira, do Estado do Rio Grande do Sul ao do Espírito Santo, constituindo a maior parte das indústrias de gumes cortantes. Outros locais em que o quartzo foi utilizado são as regiões de Diamantina, Corinto, serras do Cipó e do Cabral e bacia do rio Doce (no estado de Minas Gerais), serra dos Carajás (estado do Pará) e Sul do Brasil. Em alguns sítios, vários tipos de quartzo foram utilizados, como no sítio Gruta do Gavião (em Carajás), onde foram registrados os tipos leitoso, citrino, ametista e hialino, este último buscado a mais de $50 \mathrm{~km}$ do sítio (Hilbert 1993: 23). Um estudo específico sobre 
lascamento de cristais de quartzo no município de Jequitaí (Minas Gerais) foi feito por Bassi (2012).

\section{Calcedônia}

As duas formas cripto e microcristalinas mais abundantes de sílica são a calcedônia e a ágata. Nelas, o conteúdo em água pode variar de 0,1 a $4 \%$, e as impurezas excedem $1 \%$. A calcedônia ocorre comumente nos geodos dos basaltos, em silcretes e em zonas de silicificação de várias origens. Por ter estrutura fibrosa, deve ser trabalhada pelo lascador no sentido da fibra, que guia a fratura. A maioria delas apresenta uma forte resistência à compressão e à tração. São conhecidos sítios arqueológico com utilização desta matéria-prima no estado do Pará (sítio Pedra Pintada), na serra da Capivara (estado do Piauí), no Brasil Central e Sul do Brasil.

\section{Ágata}

A ágata é uma variedade muito dura e bastante tenaz de calcedônia, apresentando-se em faixas paralelas, retas ou curvas, de cores contrastadas. Da mesma forma que a calcedônia, ocorre comumente na forma de nódulos nos geodos das rochas vulcânicas. É comum tais geodos conterem associados quartzo hialino, ametista e calcita, e podem ser frequentes nos basaltos da bacia do Paraná. Ela é mais tenaz que o sílex e o quartzo e foi particularmente lascada no sul do estado de Santa Catarina e no norte do estado do Rio Grande do Sul. No Pantanal Mato-grossense, região de Cáceres, são conhecidas contas, pingentes e tembetás de ágata e de uma variedade vermelha de calcedônia, a cornalina, associadas à cerâmica Descalvados (Migliacio 2006).

A elevada resistência química e física das três formas de sílica (cristalina, cripto e microcristalina) faz com que as suas rochas encaixantes sejam mais facilmente intemperizadas que elas, de modo que nódulos desses materiais ocorriam soltos nas encostas ou constituíram, em certas áreas, seixos fluviais disponíveis para as populações pré-históricas.

\section{Feldspato}

Ainda que pouco frequente, outro material silicoso de uso arqueológico é o feldspato, em cores branca, cinza clara, bege, róseo e verde (amazonita). Em sítios arqueológicos da região de Carajás há contas de feldspato perfurado (Jacqueline Rodet, com. verbal). Tembetás de amazonita em contexto de cerâmica Tupiguarani são conhecidos no Rio Doce e no município de Florestal, ambos em Minas Gerais (A. Prous, com. verbal). Outras matériasprimas verdes, embora não silicosas, como os esteatitos, foram empregadas para a confecção de "ídolos" (estatuetas líticas), notadamente nas proximidades dos municípios de Santarém, Óbidos e Oriximiná (Aires da Fonseca 2007: 256), no baixo vale do rio Amazonas.

\section{Riolitos, riodacitos, dacitos e andesitos}

Riolitos, riodacitos, dacitos e andesitos são rochas vulcânicas de ácidas a intermediárias cujo teor relativamente alto em sílica permite lascá-las. Não ocorrem de forma extensiva no Brasil (Almeida et al. 2012), constituindo exemplos de materiais utilizados no passado arqueológico os riodacitos e riolitos dos municípios de Castro e de Piraí do Sul (estado do Paraná) e aqueles conhecidos na região amazônica: alto rio Mapuera, afluente do Trombetas (Escudo das Guianas), alto rio Madeira e alto rio Tapajós (A. Prous, com. verbal). 


\section{Obsidiana}

Outra matéria-prima de origem vulcânica e de ótima qualidade para o lascamento é a obsidiana, constituída por $>77 \%$ de sílica. Associada exclusivamente a rochas vulcânicas ácidas, como em certas áreas dos Andes, da América Central, do estado de Oregon nos EUA e do México, foi nessas regiões trabalhada para uso como instrumentos e objetos decorativos de valor simbólico. Elas são raras no Brasil, pois nas maiores bacias sedimentares - do Paraná, do Parnaíba, do Amazonas e Sanfranciscana (Figura 1) - os eventos vulcânicos ocorridos no Mesozoico foram de natureza essencialmente básica, produzindo basaltos. Contudo, são conhecidos no estado do Paraná alguns instrumentos líticos de obsidiana (Cláudia Parellada, com. verbal), além de afloramentos no estado do Rio Grande do Sul (geólogo Wilson Wildner, com. verbal).

\section{Argilitos e siltitos}

Os argilitos e siltitos são rochas sedimentares essencialmente constituídas por argilominerais e silte. Caso estas litologias sejam coesas, com poucas impurezas (óxidos, carbonatos, matéria orgânica), pouco fraturadas e silicificadas, são lascáveis e apresentam fratura conchoidal, sendo nesses casos referidas por alguns arqueólogos como silexitos. Constituem exemplos lascas em abrigos de formações ferruginosas no Quadrilátero Ferrífero (Baeta \& Piló 2005), alguns artefatos líticos do vale do Peruaçu, afluente esquerdo do rio São Francisco em Minas Gerais, e parte da indústria lítica de Monte Alegre, no estado do Pará.

\section{Quartzo-arenito}

Os arenitos, bem como os argilitos e siltitos, podem ser gerados em desertos, rios, deltas, estuários, lagos, lagunas, litorais, oceanos e geleiras. Aqui serão referidos somente dois tipos de arenitos, por sua maior utilização lítica. Assim, o arenito "puro" (quartzo-arenito ou arenito quartzoso) foi muito utilizado pre-historicamente como afiador (quando é friável e esfarela), ou de forma lascada (quando compacto), e ocorre em muitos sítios situados em bacias sedimentares. Ele pode ter constituído matéria-prima importante, especialmente em áreas desprovidas de jazidas silicosas de melhor qualidade, como ao longo do litoral brasileiro (do Amapá ao Rio de Janeiro), onde constitui algumas camadas em falésias da Formação Barreiras. Em sambaquis de São Luís, no estado do Maranhão, há uma peça nucleiforme de arenito (A. Prous, com. verbal).

\section{Arenito silicificado}

De larga utilização como matéria-prima para a obtenção de variados tipos de instrumentos, corriqueiramente chamados de raspadores, facas e pontas de projétil, desde os sítios pré-históricos do estado do Tocantins até os situados no estado do Rio Grande do Sul, é $o$ arenito silicificado. Este tipo de arenito ocorre em camadas pouco espessas em contato direto com derrames vulcânicos ou com sills (ou soleiras, nome dado aos corpos ígneos formados em profundidade de conformação aproximadamente horizontal). Para a Arqueologia interessa a elevada homogeneidade dessa matéria-prima de cores amarela e vermelha, muito utilizada (não exclusivamente) para a confecção de artefatos unifaciais da "tradição" lítica Itaparica, presentes em sítios do Pleistoceno Tardio e Holoceno Inferior no Planalto Central e no Nordeste brasileiros (Lourdeau 2010, Bueno \& Dias 2015). Outro tipo de arenito silicificado de uso arqueológico é aquele formado por dissolução e precipitação de sílica causadas pela sobrecarga de sedimentos sobrepostos na bacia, cimentando os grãos de areia e dando origem, por exemplo, aos arenitos cretáceos do Grupo Urucuia. Constituem exemplos os instrumentos de geometria plano-convexa do vale do Peruaçu, em Minas Gerais, e os da 
região de Piragiba, na Bahia. No último caso citado, são conhecidas centenas de lâminas de machado lascadas de arenito silicificado em sítios da tradição Aratu do final do Holoceno (Fernandes 2014).

\section{Quartzito}

O quartzito constituiu outra matéria-prima silicosa muito empregada pelas populações pré-históricas. Utilizado como percutor, alisador de cerâmica e suporte para afiação de artefatos líticos polidos (além do arenito) quando abrasivo e poroso; e usado para a obtenção de instrumentos de corte, raspagem e perfuração quando a trama de seus grãos ou cristais é "fechada", devido à recristalização ocorrida no processo metamórfico que lhe deu origem. Quartzitos ocorrem em muitas áreas dos Escudos Cristalinos. Apenas para mencionar alguns exemplos de Minas Gerais, tem-se sítios arqueológicos nos municípios de Jequitaí, Buritizeiro, Lagoa dos Patos (Rodet \& Duarte 2012, Penha 2015) e Arcos, além dos localizados na serra do Cipó e na região de Diamantina (retoque de plaquetas). Na serra da Capivara, situada no estado do Piauí, o quartzito é frequente nas indústrias líticas, além do sílex e do silcrete (Rioda et al. 2011).

\section{Discussões e conclusões}

A utilização crescente de conceitos e técnicas oriundas das Geociências nas pesquisas arqueológicas brasileiras tem demonstrado que estas apresentam um potencial de abordagem de maior amplitude, e em muitos casos mais eficaz, quando tal interdisciplinaridade se faz presente. Apesar de esta interdisciplinaridade estar sendo incrementada nos últimos decênios, o ensino teórico de Geoarqueologia e a sua prática nos cursos de Arqueologia do Brasil precisam ser mais difundidos, seja nos próprios cursos, seja em associação com os cursos de Geologia e Geografia das mesmas universidades. Tal prática auxiliaria sobremaneira os egressos da graduação e pós-graduação em Arqueologia a distinguirem, entre as matériasprimas líticas silicosas que macroscopicamente são similares, os tipos de quartzo, e estes do sílex, do cherte, da calcedônia, do silcrete, do arenito silicificado e do quartzito fino. Isto contribuiria também para a identificação e distinção em campo de outras matérias-primas, bem como para o entendimento das paisagens (no sentido fisiográfico) sob estudo. A relativa escassez das ocorrências de sílex "puro”, e a quase ausência da obsidiana, nas áreas dos Escudos Cristalinos e das Bacias Sedimentares no Brasil, matérias-primas de excelente qualidade para a obtenção de gumes cortantes, levou muitas populações pré-históricas a buscarem materiais silicosos que os substituíssem. Trata-se do quartzo, ágata, hematita, além do arenito, siltito e calcário silicificados, e do quartzito, especialmente o de grão fino, embora esses materiais não respondam, na cadeia operatória, da mesma maneira que as primeiras. A carência de mapas geológicos de acesso público nas escalas de detalhe, ou mesmo de semidetalhe, representando a maioria do território brasileiro, constitui outro elemento dificultador para os estudiosos das indústrias líticas, especialmente quando preocupados em rastrear possíveis jazidas fontes das matérias-primas, sejam silicosas ou representadas por quaisquer litologias que afloram por áreas reduzidas, como sillimanita, hematita, pirolusita, feldspato e diabásio. Um contexto geológico que merece atenção nos estudos sobre economia de captação de matérias-primas é representado pelas áreas com exposição de cascalhos fluviais e litorâneos, pois tais jazidas secundárias podem conter não apenas uma variabilidade lítica considerável, como são úteis para rastrear as jazidas primárias desses materiais. As tabelas e figuras aqui apresentadas, referentes aos grandes domínios geológicos e fisiográficos brasileiros e às matérias-primas mais frequentes neles encontradas, a despeito de sua generalização, podem servir de apoio aos estudiosos das indústrias líticas do Brasil. No 
futuro, um conhecimento maior das jazidas líticas poderá permitir a identificação mais precisa de fontes, tal como se pratica na Europa há tempo (Miskovsky 1987).

\section{Agradecimentos}

Agradeço profundamente às sugestões apresentadas pelo professor André Prous (UFMG) e pelo amigo Luydy Fernandes (UFRB/CAHL). Sou igualmente grato ao apoio na configuração das tabelas e formatação final do texto, feitas por Jéssica Cândido, e à tradução para o inglês de Ariadne Núñez, do curso de Geologia da UNIBH-Centro Universitário Belo Horizonte. Ao amigo Pe. Lauro Palú, do Santuário do Caraça, em Catas Altas, meu obrigado pela revisão ortográfica.

\section{Referências}

Áb'Sáber, A.N. 1967, Domínios morfoclimáticos e províncias fitogeográficas do Brasil. Orientação, Instituto de Geografia da Universidade de São Paulo, 3: 45-48. (in Portuguese) ("Morphoclimatic domains and fitogeographic provinces of Brasil”)

Áb'Sáber, A.N. 1971, A Organização Natural das Paisagens Inter e Subtropicais Brasileiras. In: Simpósio sobre o Cerrado, Editora Edgard Blücher, São Paulo: p. 1-14. (in Portuguese) ("The natural organization of the inter and subtropical Brazilian landscapes”)

Áb'Sáber, A.N. 2005, Os Domínios de Natureza no Brasil. Potencialidades Paisagísticas. $3^{\mathrm{a}}$ ed. Ateliê Editorial, São Paulo, 159 p. (in Portuguese) ("The domains of nature in Brazil. Landscape potentials”)

Aires da Fonseca, J. 2007, Do Século XIX ao XX: cartas e publicações sobre os ídolos de pedra amazônicos. História e História, 06 de agosto de 2007. (in Portuguese) ("From the $19^{\text {th }}$ to $20^{\text {th }}$ century: Letters and publications about Amazonian stone idols") Acesso em 25 out. 2009 URL: http://historiahistoria.com.br/materia.cfm?tb=arqueologia\&id=9

Akhavan, A.C. 2010, The Quartz Page. Hamburg. (in English) ("A página do quartzo"). Acesso em 06 de mar 2017. URL: http://www.quartzpage.de/

Almeida, F.F.M.; Carneiro, C.D.R.; Bartorelli, A. 2012, Magmatismo Pós-Paleozoico no Brasil. In: Geologia do Brasil (Hasui, Y., Carneiro, C.D.R., Almeida, F.F.M., \& Bartorelli, A., Eds.), Beca, São Paulo: p. 430-452. (in Portuguese) ("Post-palaeozoic magmatism in Brazil”)

Araujo, A.G.M. 1991, As rochas silicosas como matéria-prima para o Homem Pré-Histórico: variedades, definições e conceitos. Revista do Museu de Arqueologia e Etnologia, 1: 105-111. (in Portuguese) ("The siliceous rocks as raw material to prehistoric humans: Varieties, definitions and concepts")

Araujo, A.G.M. 1992, As propriedades físicas dos arenitos silicificados e suas implicações na aptidão ao lascamento. Revista do Museu de Arqueologia e Etnologia, 2: 63-74. (in Portuguese) ("The physical properties of silicified sandstones and their implications in the knapping fitness”) doi:10.11606/issn.2448-1750.revmae.1992.108993

Araujo, A.G.M. 2013, Geomorfologia e Paleoambientes no Leste da América do Sul. Implicações arqueológicas. In: Geoarqueologia (Rubin, J.C.R. \& Silva, R.T, Eds.), Editora da Pontifícia Universidade Católica de Goiás, Goiânia: p. 135-180. (in 
Portuguese) (“Geomorphology and palaeoenvironments in eastern South America. Archaeological Implications”)

Baeta, A. \& Piló, H. 2005, Arqueologia do Quadrilátero Ferrífero. Aspectos preliminares sobre sua ocupação. Estudo de caso do Capão Xavier. Carste, 17(3): 116-131. (in Portuguese) ("Iron Quadrangle archaeology. Preliminary aspects on its occupation”)

Barthelmy, D. 2014, Mineralogy Database. (in inglês) ("Banco de dados de mineralogia"). Acesso em 11 de jun 2016. URL: http://webmineral.com/

Barreto, A.M.F. 1996, Interpretação paleoambiental do Sistema de dunas fixadas do médio Rio São Francisco, Bahia. Tese de Doutorado. Instituto de Geociências da Universidade de São Paulo, São Paulo, 175 p. (in Portuguese) ("Paleoenvironmental interpretation of the dunes system in the middle São Francisco river”)

Bassi, L.F. 2012, Tecnologia lítica: Análise diacrônica dos níveis mais antigos do sítio arqueológico Bibocas II, Jequitaí - MG. Dissertação de Mestrado. Universidade Federal de Minas Gerais, Belo Horizonte, 286 p. (in Portuguese) ("Lithic technology:

Diachronic analysis of the most ancient levels of the Bibocas II archaeological site, Jequitaí - MG”)

Bates, R.L. \& Jackson, J.A. (Eds.), 1987, Glossary of Geology, $3^{\text {rd }}$ ed. American Geological Institute, Alexandria, Va., 788 p. (em inglês) (Glossário de Geologia)

Behling, H. 1996, First report on new evidence for the occurrence of Podocarpus and possible human presence at the mouth of the Amazon during the Late-glacial. Vegetation History and Archaeobotany, 5(3): 241-246. (em inglês) ("Primeiro registro sobre nova evidência da ocorrência de Podocarpus e possível presença humana na foz do Amazonas durante o Glacial tardio”) doi:10.1007/BF00217501

Brandl, M. 2010, Classification of rocks within the chert group: Austrian practice. Archeometriai Mühely, 3: 183-190. (em inglês) (“Classificação de rochas dentro do grupo dos chertes: Prática austríaca”)

Bueno, L.M.R. 2006, As indústrias líticas da região do Lajeado e sua inserção no contexto do Brasil Central. Revista do Museu de Arqueologia e Etnologia, 15-16(2005-2006): 1-21. (in Portuguese) ("The lithic industries in the Lajeado region and its insertion in Central Brazil context”) doi:10.11606/issn.2448-1750.revmae.2006.89708

Bueno, L.M.R. \& Dias, A. 2015, Povoamento inicial da América do Sul: contribuições do contexto brasileiro. Estudos Avançados, 29(83): 119-147. (in Portuguese) (“The Initial Peopling of South America: Contribution from the Brazilian context”) doi:10.1590/S0103-40142015000100009

Cornejo, C. \& Bartorelli, A. 2010, Minerais e Pedras Preciosas do Brasil. Solaris Edições Culturais, São Paulo, 704 p. (in Portuguese) ("Minerals and Precious stones from Brasil”)

Dana, J.D. \& Hurlbut, C.S. 1974, Manual de Mineralogia. Livros Técnicos e Científicos, Rio de Janeiro, 653 p. (in Portuguese) ("Manual of Mineralogy")

Dias-Brito, D. \& Tibana, P. 2015, Calcários do Cretáceo do Brasil. Um Atlas. Universidade Estadual Júlio de Mesquita Filho-Instituto de Geociências e Ciências Exatas-Centro de Geociências Aplicadas ao Petróleo, Obra 1, Rio Claro, 576 p. (in Portuguese) ("Limestones from the Brazilian Cretaceous") 
Fernandes, L.A. 2014, Possibilidades da análise tecnomorfológica das lâminas de machado lascadas de sítios da tradição Aratu na Bahia. In: Indústrias líticas na América do Sul: abordagens teóricas e metodológicas, Vol. 1 (Lourdeau A.; Viana, S.A.; Rodet, M.J., Eds.), Editora da Universidade Federal de Recife, Recife: p.91-122. (in Portuguese) ("Possibilities of the technomorphological analysis of the flaked axe blades from Aratu tradition sites in Bahia State”)

Haffer, J. 1969, Speciation in Amazonian Forests Birds. Science, New Series, 165(3889): 131137. (em inglês) ("Especiação em pássaros da Floresta Amazônica”) doi:10.1126/science.165.3889.131

Hallsworth, C.R. \& Knox, R.W.O’B. 1999, British Geological Survey Rock Classification Scheme, Vol. 3. Classification of sediments and sedimentary rocks. Research Report. Number RR 99-03, Nottinghan, UK, 44 p. (em inglês) (“Classificação de sedimentos e de rochas sedimentares")

Hasui, Y.; Carneiro, C.D.R.; Almeida, F.F.M.; Bartorelli, A. 2012, Geologia do Brasil. Beca, São Paulo, 900 p. (in Portuguese) ("Geology of Brasil”)

Hilbert, K. 1993, Organização e uso do espaço de grupos caçadores-coletores pré-históricos na gruta do Gavião, serra dos Carajás (PA). Relatório. Pontifícia Universidade Católica (PUC), Porto Alegre, 87 p. (in Portuguese) ("Prehistoric hunter gatherer groups organization and use of space in Gruta do Gavião, Serra dos Carajás (PA)”)

Instituto Brasileiro de Geografia e Estatística (IBGE) 1999, Glossário Geológico. IBGE, Rio de Janeiro, 214 p. (in Portuguese) (“Geological glossary”)

Klein, C. \& Dutrow, B. 2012, Manual de Ciências dos Minerais. Tradução e revisão técnica: Rualdo Menegat. 23 $3^{\text {rd }}$ ed. Bookman, Porto Alegre, 706 p. (in Portuguese) ("Manual of the sciences of minerals")

Knauth, L.P. 1994, Petrogenesis of chert. Reviews in Mineralogy, 29: 233-258 (em inglês) ("Petrogênese do cherte") URL: https://pubs.geoscienceworld.org/msa/rimg/article/29/1/233/110562/

Latrubesse, E.M.; Stevaux, J.C.; Santos, M.L.; Assine, M.L. 2005, Grandes Sistemas Fluviais. In: Quaternário do Brasil (Souza, C.R.G.; Suguio, K.; Oliveira, A.M.S.; Oliveira, P.E., Eds.), Associação Brasileira de Estudos do Quaternário. Holos Editora, Ribeirão Preto: p. 276-297. (in Portuguese) (“Great fluvial systems”)

Lima da Costa, M.; Behling, H.; Suguio, K.; Kaempf, N.; Kern, D.C. 2009, Paisagens Amazônicas sob a Ocupação do Homem Pré-histórico: Uma Visão Geológica. In: As Terras Pretas de Índio da Amazônia: Sua Caracterização e Uso deste Conhecimento na Criação de Novas Áreas (Teixeira, W.G., Kern, D.C., Emöke Madari, B.E., Lima, H.N., \& Woods, W., Eds.), Empresa Brasileira de Pesquisa Agropecuária. Manaus: p. 15-38. (in Portuguese) (“Amazonian landscapes under prehistoric humans occupation: A geological vision”)

Lourdeau, A. 2010, Le Technocomplexe Itaparica - definition techno-fonctionnelle des industries à pieces façonnées unifacialement à une face place dans le centre et le nordest du Brésil pendant la transition Pleistocène-Holocène et l'Holocène ancient. Tese de Doutorado, Université Paris Ouest Nanterre La Défense, Paris, 686 p. (em francês) (O tecnocomplexo Itaparica - definição tecnofuncional das indústrias de peças façonadas unifacialmente opostas a uma face plana no centro e nordeste do Brasil durante a transição Pleistoceno-Holoceno e Holoceno inicial) (in French) ("The Itaparica 
technocomplex - technofucntional definition of the unifacial reducted artifacts opposed to a flat surface in the center and northeastern Brasil during the Pleistocene-Holocene transition and Early Holocene”)

Melo, M.S.; Riccomini, C.; Hasui, Y.; Almeida, F.F.M.; Coimbra, A.M. 1985. Geologia e evolução do sistema de bacias tafrogênics continentais do sudeste do Brasil. Revista Brasileira de Geociências, 15(3): 193-201. (in Portuguese) ("Geology and evolution of the continental tafrogenic basins system of the Southeast of Brazil”)

Migliacio, M.C. 2006, O doméstico e o ritual: cotidiano Xaray no alto Paraguai até o século $X V I$. Tese de Doutorado, Museu e Arqueologia e Etnologia da Universidade de São Paulo, São Paulo, 464 p. (in Portuguese) (“The domestic and the ritual: The Xaray daily life in the upper Paraguay river until XVI ${ }^{\text {th }}$ century")

Miskovsky, J.C. (ed.). 1987, Géologie de la Préhistoire: Méthodes, Techniques, Applications, Paris, 1297 p. (em francês) (Geologia da pré-história: Métodos, técnicas, aplicações) (in french) ("Geology of the prehistory: Methods, techniques, applications")

Oliveira, P.E.; Behling, H.; Ledru, M.P.; Barberi, M.; Bush, M.; Salgado-Labouriau, M.L.; Garcia, M.J.; Medeanic, S.; Barth, O.M.; Barros, M.A.; Scheel-Ybert, R. 2005, Paleovegetação e paleoclimas do Quaternário do Brasil. In: Quaternário do Brasil (Souza, C.R.G.; Suguio, K.; Oliveira, A.M.S.; Oliveira, P.E., Eds.), Associação Brasileira de Estudos do Quaternário. Holos Editora, Ribeirão Preto: p. 52-74. (in Portuguese) ("Paleovegetation and paleoclimates during the Quaternary in Brazil")

Penha, U.C. 2008, O Patrimônio paleontológico da bacia do Rio Doce em Minas Gerais e no Espírito Santo. Centro Europeu de Investigação da Pré-História do Alto Ribatejo. Area Domeniu, 3: 79-92. (in Portuguese) ("The paleontological heritage from the Rio Doce basin in Minas Gerais and Espírito Santo states”)

Penha, U.C. 2015, Prospecção de Jazidas Líticas em Arqueologia: uma Proposta Metodológica. Dissertação de Mestrado. Programa de Pós-Graduação em Antropologia, Universidade Federal de Minas Gerais, Belo Horizonte, 227 p. (in Portuguese) ("Prospecting of lithic deposits in Archaeology: A methodological proposal")

Penha, U.C. \& Prous, A. 2017, Principais rochas utilizadas e trabalhadas durante a PréHistória. In: O Estudo dos Instrumentos de Pedra: Fabricação, Utilização e Transformação dos Artefatos (Prous, A. \& Fogaça, E., Eds.), Alínea Publicações Editora, Teresina: p. 44-63. (in Portuguese) ("Mainly used and worked rocks during prehistory”)

Press, F.; Siever, R.; Grotzinger, J.; Jordan, T.H. 2006, Para Entender a Terra. Bookman, $4^{\mathrm{a}}$ ed., Porto Alegre, 656 p. (in Portuguese) (“To understand the Earth”)

Prichystal, A. 2010, Classification of lithic raw materials used for prehistoric chipped artefacts in general and siliceous sediments (silicites) in particular: The Czech proposal. Archeometriai Mühely, 3: 177-181. (em inglês) ("Classificação de matérias-primas líticas utilizadas para artefatos lascados pré-históricos em sedimentos em geral e em silicosos em particular: uma proposta tcheca”)

Prous, A.P. 1992, Arqueologia Brasileira. $2^{\mathrm{a}}$ ed. Editora da Universidade de Brasília, Brasília, 613 p. (in Portuguese) ("Brazilian Archaeology”)

Prous, A.P. 2004, Apuntes para análisis de industrias líticas. Ortegalia (Monografías de Arqueoloxía, Historia e Patrimonio) Vol. 2., Fundación Federico Maciñeira, Ortigueira, 
172 p. (em espanhol) (Apontamentos para análise de indústrias líticas) (in spanish) (“Appointments for the analysis of lithic industries”)

Prous, A.P.; Isnardis, A.; Pessoa Lima, A.; Alonso, M.; Piló H.; Migliacio, M.C. 2009, Matières premières “alternatives” dans le Brésil Central: Quartz, quartzite, agate et hématite. In: Non-Flint Raw Material Use in Prehistory (Sternke, F.; Eigeland, L.; Costa, L.J., Eds.), Union Internationale des Sciences Préhistoriques et Protohistoriques, 2006, Lisboa, 11(77), Bar International Series Vol. 1939, Archaeopress, Oxford: p. 133143. (em francês) (Matérias-primas "alternativas” no Brasil Central: quartzo, quartzito, ágata e hematita) (in french) (“Alternative” Raw materials in Central Brazil: Quartz, quarzite, agate and hematite")

Rapp, G. Jr. \& Hill, C. 1998, Geoarchaeology. The Earth-Science Approach to Archaeological Interpretation. Yale University Press, London, 274 p. (em inglês) (“Geoarqueologia. A abordagem da Ciência Terra para interpretação arqueológica”)

Rioda, V.; Candelato, F.; Mota, L.; Parenti, F. 2011, Jazidas de rochas silicosas na área do Parque Nacional Serra da Capivara (Piauí, Brasil): primeiros dados geoarqueológicos. Revista do Museu de Arqueologia e Etnologia, 21: 103-113. (in Portuguese) (“Siliceous rocks sources in the Serra da Capivara National Park (Piauí State, Brazil): First geoarchaeological data”)

Rodet, M.J. \& Duarte, D. 2012, Arqueologia na região de Jequitaí e Buritizeiro/MG: em busca da variabilidade regional do registro arqueológico pré-histórico. Relatório de campo-Prospecção. Universidade Federal de Minas Gerais, Belo Horizonte, 14 p. (in Portuguese) ("Archaeology in the Jequitaí em Buritizeiro region, MG: Towards the regional variability of the prehistorical archaeological record”)

Rodet, J.; Rodet, M.J.; Willems, L.; Pouclet, A. 2009, Abordagem geomorfológica da bacia do rio Peruaçu e implicações geoarqueológicas. Arquivos do Museu de História Natural e Jardim Botânico / Universidade Federal de Minas Gerais, Tomo I, 19: 75-103. (in Portuguese) ("Geomorphological approach of Peruaçu river basin and geoarchaeological implications”)

Rodet, M.J.; Guapindaia, V.; Matos, A. 2010, Análise tecnológica e cadeia operatória: uma nova proposta para a indústria lítica lascada das culturas ceramistas da Amazônia. In: Arqueologia Amazônica, Vol. 2 (Pereira, E. \& Guapindaia, V., Eds.), Museu Paraense Emílio Goeldi, Belém: p. 681-711. (in Portuguese) (“Technological analysis and operative chain: A new proposal to the flaked lithics industry of the ceramic cultures in the Amazon")

Ross, J.L.S. 1991, O relevo brasileiro, as superfícies de aplanamentos e os níveis morfológicos. Revista do Departamento de Geografia, 5: 7-24. (in Portuguese) ("The Brazilian relief, the flat surfaces and morphological levels") doi:10.7154/RDG.1991.0005.0001

Sallun Filho, W. \& Karmann, I. 2012, Províncias cársticas e cavernas no Brasil. In: Geologia do Brasil (Hasui, Y.; Carneiro, C.D.R.; Almeida, F.F.M.; Bartorelli, A., Eds.), Beca, São Paulo: p. 629-641. (in Portuguese) ("Carstic provinces and caves in Brazil”)

Santos, D.B.; Montalvão, R.M.G.; Rodriques, O.B.; Leal, J.W.L. 1982, Coberturas vulcanosedimentares e sedimentares pré-cambrianas da Plataforma Amazônica. In: Anais do I Simpósio de Geologia da Amazônia : Belém, PA, maio 1982, Sociedade Brasileira de Geologia, Belém: p. 163-184. (in Portuguese) ("Precambrian volcano-sedimentary and sedimentary covers of the Amazonian platform”) 
Shepherd, W. 1972, Flint: Its Origin, Properties and Uses. Faber and Faber, London, 255 p. (em inglês) (Silex: Suas origens, propriedades e uso")

Sgarbi, G.N.C. (Ed.) 2007, Petrografia Macroscópica das Rochas Ígneas, Sedimentares e Metamórficas. Editora da Universidade Federal de Minas Gerais, Belo Horizonte, 557 p. (in Portuguese) ("Macroscopic petrography of igneous, sedimentary and metamorphic rocks”)

Suguio, K. 1980, Rochas Sedimentares. Editora Edgard Blücher, São Paulo, 500 p. (in Portuguese) ("Sedimentary rocks")

Suguio, K. 2005, Introdução. In: Quaternário do Brasil (Souza, C.R.G.; Suguio, K.; Oliveira, A.M.S.; Oliveira, P.E., Eds.), Associação Brasileira de Estudos do Quaternário, Holos Editora, Ribeirão Preto: p. 21-27. (in Portuguese) (“Introduction”)

Suguio, K.; Angulo, R.J.; Carvalho, A.M.; Corrêa, I.C.S.; Tomazelli, L.J.; Willwock, J.A.; Vital, H. 2005, Paleoníveis do Mar e Paleolinhas de Costa. In: Quaternário do Brasil (Souza, C.R.G.; Suguio, K.; Oliveira, A.M.S.; Oliveira, P.E., Eds.), Associação Brasileira de Estudos do Quaternário. Holos Editora, Ribeirão Preto: p. 114-149. (in Portuguese) ("Sea paleolevels and coast paleolines”)

Suguio, K. 2007, Geologia Sedimentar. Editora Edgard Blücher, São Paulo, 400 p. (in Portuguese) ("Sedimentary geology”)

Vanzolini, P. 1992, Paleoclimas e especiação em animais da América do Sul tropical. Estudos Avançados, 6(15): 41-65. (in Portuguese) ("Palaeoclimates and speciation in animals from tropical South America”)

Wentworth, C.K. 1922, A scale of grade and class terms for clastic sediments. Journal of Geology, 30: 377-392. (em inglês) ("Uma escala de grau e de termos de classificação para sedimentos clásticos”)

Williams, H.; Turner, F.J.; Gilbert, C.M. 1970, Petrografia. Uma Introdução ao Estudo das Rochas em Seções Delgadas. Polígono, São Paulo, 445 p. (in Portuguese)

("Petrography. An introduction to the Study of rocks in thin sections")

Winge, M., (Ed.) 2016, Glossário Geológico Ilustrado. CPRM-Serviço Geológico do Brasil, Brasília. (in Portuguese) ("Ilustrated geological glossary”). Acesso em 19 de ago. 2016. URL: http://sigep.cprm.gov.br/glossario/

Zalán, P.V. 2004, Evolução fanerozóica das bacias sedimentares brasileiras. In: Geologia do Continente Sul-Americano: Evolução da Obra de Fernando Flávio Marques de Almeida (Mantesso-Neto, V.; Bartorelli, A.; Carneiro, C.D.R.; Brito-Neves, B.B., Eds.), Beca, São Paulo: p. 595-612. (in Portuguese) ("Fanerozoic evolution of the Brazilian sedimentary basins”) 


\title{
Brazilian lithic raw materials occurrences: A geological approach
}

\author{
Ulisses Cyrino Penha
}

Archaeology Department of the Museu de História Natural e Jardim Botânico da Universidade Federal de Minas Gerais - UFMG. Rua Gustavo da Silveira, 1035. Santa Inês. Belo Horizonte, Minas Gerais, Brazil.

Email: ulisses.penha@gmail.com

\begin{abstract}
:
The main purpose of the current study is to help researchers and students studying lithics in Brazilian archaeology to understand, through a macro-regional scale, the potential sources of the main occurrences of lithic raw materials in Brazil. This potential is presented from a qualitative point of view and has been divided along two perspectives. The first approach recalls the geological areas known as shields. These are the Guianas, Central Brazil, and Atlantic, and together, they account for $57.3 \%$ of the national territory. The sedimentary basins, more significant in size, are the Amazonas, Foz do Amazonas, Parnaíba, Sanfranciscana, Pantanal and Paraná, and account for the remaining $42.7 \%$ of the terrain. The second approach presents the lithic potential according to the major geomorphologic domains called the Amazonian, Cerrado, Mares de Morros, Caatinga, Mata de Araucárias, Prairies and Transition Zones, although this paper focuses only on the first four mentioned. Properly defining the nature of the lithic raw materials has been an issue for archaeologists, particularly those materials whose macroscopic features are similar and very fine grained, such as flint, chert, chalcedony, silcrete, silicified sandstone and fine sandstone. The lack of field activities in Brazilian archaeology courses results in not providing a minimum basis in mineralogy, geology and geomorphology for archaeology works to be carried out properly. In cases where the archaeological lithic studies are the main subject of the work or research, the scenario may be even worse due to the lack of availability of public domain geological maps at appropriate scale, in such a way that the small rock bodies, often classified as potential lithic occurrences, are not represented. To be used both in reference work, field research and laboratory stages, this paper provides simplified schemes of classification and identification for the most common rocks and minerals found at archaeological sites in Brazil, also mentioning the basic processes of rocks formation. Aging more than 541 million years, the shields are formed mainly by igneous intrusive and metamorphic rocks and their height ranges from 300 to 3000 meters. Their main raw materials, potentially useful for the lithic industries, are the granites, granodiorites, gabbros, diabases, amphibolites, quartzites, gneisses, iron formations, metamorphosed limestones, soapstones, jaspilites, laterites, quartz, hematite, manganese oxides and, more rarely, sillimanite and amazonite. Constituted by sedimentary and extrusive rocks as well as sediments, and located in regions whose altitude is below 300 meters high, the sedimentary basins age less than 541 million years. The most frequent sedimentary rocks, which are useful for the lithic industry, are sandstones, siltstones, arkoses, limestones and less commonly silexites and cherts; the main volcanic rocks are basalts, less frequently rhyolites and rhyodacites and very rare obsidians; among the minerals, can be mentioned agate, chalcedony and quartz; and gravel pebbles, laterites and silcretes as Tertiary-Quaternary sediments. The pebbles of fluvial and coastal gravels can contain certain rocks and minerals from practically all examples mentioned in the shields and sedimentary basins. The Brazilian river system, constituted by abundant water bodies, most of them draining shield areas and rugged terrains in basins,
\end{abstract}


provided in the archaeological past a significant lithologic variety for those human populations, and such condition must be considered in the lithic studies in Brazil.

Keywords: lithic raw materials; lithic prospection; geoarchaeology; Brazil 